\title{
Molecular composition of soil organic matter with land-use change along a bi-continental mean
}

annual temperature gradient

Oliva Pisani $^{\mathrm{a}}$, Michelle L. Haddix ${ }^{\mathrm{b}}$, Richard T. Conant ${ }^{\mathrm{b}}$, Eldor A. Paul ${ }^{\mathrm{b}}$, and Myrna J. Simpson ${ }^{\mathrm{a}^{*}}$

${ }^{a}$ Environmental NMR Centre and Department of Physical and Environmental Sciences, University of Toronto, 1265 Military Trail, Toronto, ON. M1C 1A4, Canada.

${ }^{\mathrm{b}}$ Natural Resource Ecology Laboratory, Colorado State University, Fort Collins, CO. 80523, USA.

*Corresponding author. Tel.: +1 416-287-7234; Fax: +1 416-287-7279. E-mail address: myrna.simpson@utoronto.ca

\section{Abstract}

Soil organic matter (SOM) is critical for maintaining soil fertility and long-term agricultural sustainability. The molecular composition of SOM is likely altered due to global climate and land-use change; but rarely are these two aspects studied in tandem. Here we used molecular-level techniques to examine SOM composition along a bi-continental (from North to South America) mean annual temperature (MAT) gradient from seven native grassland/forest and cultivated/pasture sites. Biomarker methods included solvent extraction, base hydrolysis and cupric (II) oxide oxidation for the analysis of free lipids of plant and microbial origin, ester-bound lipids from cutin and suberin, and lignin-derived phenols, respectively. Solid-state ${ }^{13} \mathrm{C}$ nuclear magnetic resonance (NMR) was used to examine the overall composition of SOM. Soil cultivation was found to increase the amount of microbial-derived compounds at warmer temperatures (up to $17 \%$ increase). The cultivated soils were characterized by much lower contributions of plant-derived SOM components compared to the native soils (up to $64 \%$ lower at the coldest site). In addition, cultivation caused an increase in lignin and cutin degradation (up to 68 and $15 \%$ increase, respectively), and an increase in the amount of suberin-derived inputs (up to 54 $\%$ increase). Clear differences in the molecular composition of SOM due to soil cultivation were observed in soils of varying mineral composition and were attributed to disturbance, different vegetation inputs, soil aggregate destruction and MAT. A high organic allophanic tropical soil was characterized by 
its protection of carbohydrates and nitrogen-containing compounds. The conversion of native to cultivated land shows significant shifts in the degradation stage of SOM. In particular, cutin-derived compounds which are believed to be part of the stable SOM pool may undergo enhanced degradation with long-term cultivation and disruption of soil aggregates. On a per year basis, the total amount of cutin decreased only at the two forest sites that were converted to pasture, likely due to cutin degradation or to changes in vegetation and litter quality associated with land-use change. Overall, our study highlights that the implementation of different agricultural management practices enhances the degradation of recalcitrant SOM compounds that may become a source of atmospheric $\mathrm{CO}_{2}$ with increasing land-use and climate change.

Keywords: Soil organic carbon, biomarkers, nuclear magnetic resonance, climate change, land management, cultivated soils

\section{Introduction}

Soil organic matter (SOM) contains two-thirds of the global terrestrial carbon storage (Batjes 1996) and is critical for maintaining soil fertility and long-term agricultural sustainability (Lal 2004). The accumulation and turnover of SOM are major factors in ecosystem functioning and determine whether soils act as sinks or sources of carbon in the global carbon cycle (Post and Kwon 2000). The onset of global warming and elevated atmospheric $\mathrm{CO}_{2}$ levels and the conversion of native to agricultural land may alter the global carbon cycle through potential shifts in soil processes and $\mathrm{CO}_{2}$ emissions. The molecular-level role of SOM in ecological responses to global climate and land-use change is an emerging aspect of SOM research and understanding the fate of SOM with ecological change may help improve predictions of potential ecosystem shifts (da Silva Oliveira et al. 2016; Simpson and Simpson 2012). There is current interest in trying to understand how climate and land-use 
change may impact the molecular composition of SOM (Bahri et al. 2006; da Silva Oliveira et al. 2016; Feng et al. 2008; Nierop et al. 2001; Pisani et al. 2014; 2015; Rumpel and Chabbi 2010; Schulten et al. 1995). Knowledge of their combined influence on the accumulation and turnover of molecularly distinct SOM components is still lacking.

By the year 2100 , the mean global temperature is projected to increase by $0.3-6.4{ }^{\circ} \mathrm{C}$ (IPCC, 2007). These rising temperatures are predicted to alter many biogeochemical processes in terrestrial ecosystems (Shaver et al. 2000) and may have a direct impact on the molecular composition of SOM (Feng et al. 2008; Pisani et al. 2014; 2015). Changes in SOM composition are likely to occur through vegetation shifts (Feng et al. 2008) and through changes in the soil microbial community composition and microbial decomposition patterns of SOM (Feng et al. 2008; Frey et al. 2013). The conversion of natural vegetation to cultivated use may result in a rapid decline in SOM (Davidson and Ackerman 1993; Lal 2004; Post and Kwon 2000) and long-term management of agricultural soils may alter the quantity and the chemical structure of SOM (da Silva Oliveira et al. 2016; Conant et al. 2007; Nierop et al. 2001; Paul et al. 2003; Schulten et al. 1995). The influence of mean annual temperature (MAT) and land-use change on the bulk composition of SOM for various soils has been studied (Conant et al. 2007; Davidson and Ackerman 1993; Haddix et al. 2011; Li et al. 2013; Plante et al. 2011), but a detailed molecular-level analysis of the SOM is needed to better understand how cultivation as well as environmental factors may alter SOM biogeochemistry.

This study uses molecular-level methods to characterize SOM in soils that vary in both MAT and land-use. Soils were collected from native grassland/forest and cultivated/pasture sites along a bicontinental, longitudinal MAT gradient (Table 1). The molecular composition of the SOM was analysed using biomarkers and gas chromatography-mass spectrometry (GC-MS) in combination with solid-state ${ }^{13} \mathrm{C}$ nuclear magnetic resonance (NMR) spectroscopy. The biomarker methods employed include solvent-extraction for the analysis of free lipids of plant and microbial origin (Otto and Simpson 2005), 
base hydrolysis for the determination of ester-bound lipids from leaf cuticles and root suberin (Goñi and Hedges 1990a; Otto and Simpson 2006a) and cupric (II) oxide (CuO) oxidation for the analysis of lignin-derived phenols (Hedges and Mann 1979; Otto and Simpson 2006b). While biomarker methods

provide detailed information on specific compounds, solid-state ${ }^{13} \mathrm{C}$ NMR provides information on the bulk structure of SOM (Simpson et al. 2008). These techniques have been successfully used in tandem for the determination of SOM molecular-level responses to environmental change and land management (Feng et al. 2008; Feng and Simpson 2011; Huang et al. 2011; Pisani et al. 2014; 2015).

\section{Materials and methods}

\subsection{Sample collection}

Soil samples were collected in 2005 from seven locations along a MAT gradient: Indian Head, Saskatchewan; Mandan, North Dakota; Akron, Colorado; Vernon, Texas; Alajuela, Costa Rica; Rondônia, Brazil (Table 1). The Melfort, Saskatchewan soil sample was collected in 2000 from a cultivated site and compared with a similar Orthic Black Chernozem (Udic Boroll) grassland soil from Edmonton, Alberta that has previously been molecularly characterized (Mitchell and Simpson 2013; Otto et al. 2005). The MAT ranges from $0.8^{\circ} \mathrm{C}$ in Melfort to $25.6{ }^{\circ} \mathrm{C}$ in Rondônia, while the mean annual precipitation ranges from $402 \mathrm{~mm}$ in Mandan to $2700 \mathrm{~mm}$ in Alajuela. The temperate samples were collected from both a native grassland site and a cultivated site at each location, while the samples obtained from Costa Rica and Brazil were collected from both a native forest and pasture site located on previously forested land. Soil textural characteristics, dominant vegetation and cultivation type, and elemental composition at each location (taken from Haddix et al. 2011 and references therein) are summarized in Table 1. Surface litter and aboveground vegetation were cleared away prior to sampling and all soil samples were collected from 0-20 cm. Three field replicates were collected at each site and 
combined into one composite sample for laboratory analysis. After sampling, the soils were air-dried, passed through a $2 \mathrm{~mm}$ sieve, ground with a mortar and pestle and stored at room temperature.

\subsection{SOM biomarker extraction, analysis and quantification}

Sequential chemical extractions (solvent extraction, base hydrolysis and $\mathrm{CuO}$ oxidation) were conducted on the soil samples to analyze the free lipids, ester-bound lipids and lignin-derived phenols, respectively (Otto and Simpson 2007). The free lipids obtained through solvent extraction can be indicative of SOM sources and stage of degradation in terrestrial environments (Medeiros and Simoneit 2007; Simoneit 2005; Simpson and Simpson 2012). For example, the carbon chain length of alkyl lipids can be used to elucidate SOM sources because short-chain compounds $\left(<\mathrm{C}_{20}\right)$ are frequently considered to originate from soil microbes (Lichtfouse et al. 1995) whereas long-chain compounds $\left(\geq C_{20}\right)$ are typically derived from plant epicuticular waxes (Medeiros and Simoneit 2007). The carbon chain length maximum $\left(\mathrm{C}_{\max }\right)$ is indicative of the relative source input to soils (Bull et al. 2000; Otto and Simpson 2005; Otto et al. 2005). Free lipids also include sterols and triterpenoids. Sterols such as campesterol, stigmasterol and $\beta$-sitosterol are among the most common phytosterols in vascular plants (Hartmann 1998). The sterol ergosterol has been used as a signature lipid for fungi in soil environments (Ruzicka et al. 2000) while cholesterol has been reported in soil microbes and plant waxes and is not source specific (Hartmann 1998; Volkman 2003). Triterpenoids such as $\alpha$ - and $\beta$-amyrin, lupeol and ursolic acid, typically occur in angiosperms (Bianchi 1995). Other free lipids include the $\mathrm{C}_{16}$ mono-unsaturated monoacylglyceride which is a major constituent of cell membranes and storage lipids (fats) that are produced by many organisms (Harwood and Russell 1984). Ferulic acid originates from suberinassociated waxes (Otto and Simpson 2005). Carbohydrates, including glucose, mannose and sucrose, have been observed in animals, plants and soil microbes (Simoneit et al. 2004) and are not source specific. Trehalose is synthesized as a stress protectant and energy reserve carbohydrate by soil fungi 
and bacteria (Koide et al. 2000) although it can also be biosynthesized by some plants (Wingler 2002). To obtain these free lipids, the soils $(\sim 15 \mathrm{~g})$ were solvent-extracted in triplicate by sonication for $15 \mathrm{~min}$ with $30 \mathrm{ml} \mathrm{CH} \mathrm{Cl}_{2}, \mathrm{CH}_{2} \mathrm{Cl}_{2}: \mathrm{MeOH}(1: 1 \mathrm{v} / \mathrm{v})$ and $\mathrm{MeOH}$. The combined solvent extracts were filtered through glass fiber filters (Whatman GF/A and GF/F), concentrated by rotary evaporation and dried under a $\mathrm{N}_{2}$ stream in $2 \mathrm{ml}$ glass vials. The remaining soil residues from solvent extraction were air-dried and then subjected to base hydrolysis to yield ester-linked lipids (Goñi and Hedges 1990a; Otto and Simpson 2006a). Ester-linked lipids can be attributed to cutin (short-chain mid-chain hydroxyl acids, $\mathrm{C}_{16}$ mono- and dihydroxy acids and dioic acids), suberin (long-chain $\omega$-hydroxyalkanoic and dioic acids, and 9,10-epoxy- $\omega$-hydroxy $\mathrm{C}_{18}$ acid $)$ or both macromolecules $\left(\mathrm{C}_{16} \omega\right.$-hydroxyalkanoic acid, $\mathrm{C}_{18}$ di- and trihydroxy acids, $\mathrm{C}_{16}$ and $\mathrm{C}_{18}$ dioic acids; Kolattukudy 1980; Otto and Simpson 2006a). In addition, the suberin to cutin ratio $(\mathrm{S} / \mathrm{C})$ can be used to determine inputs of fresh root litter and leaf cuticles to soils (Kögel-Knabner et al. 1989; Otto and Simpson 2006a). Changes in the relative abundances of the $\omega$ hydroxy acids can be expressed as the $\omega-\mathrm{C}_{16} / \Sigma \mathrm{C}_{16}$ ratio which has been reported to increase with progressive cutin degradation in coastal marine sediments (Goñi and Hedges 1990b) and in soils from western Canada (Otto and Simpson 2006a). For base hydrolysis, the soil residues from solvent extraction $(0.1-3 \mathrm{~g})$ were heated at $100{ }^{\circ} \mathrm{C}$ for $3 \mathrm{~h}$ in Teflon-lined bombs with $20 \mathrm{ml}$ of $1 \mathrm{M}$ methanolic $\mathrm{KOH}$. The extracts were sonicated twice with $15 \mathrm{ml} \mathrm{CH}_{2} \mathrm{Cl}_{2}: \mathrm{MeOH}(1: 1 v / v)$, centrifuged and acidified to $\mathrm{pH} 1$ with $6 \mathrm{M} \mathrm{HCl}$. The solvents were removed by rotary evaporation and the lipids were recovered from the water phase by liquid-liquid extraction $(3 \times)$ with $30 \mathrm{ml}$ diethyl ether. The extracts were dried with anhydrous $\mathrm{Na}_{2} \mathrm{SO}_{4}$, concentrated by rotary evaporation and dried under a $\mathrm{N}_{2}$ stream in 2 ml glass vials. The base hydrolysis residues were air-dried and further oxidized with $\mathrm{CuO}$ to release ligninderived phenols (Hedges and Mann 1979; Otto and Simpson 2006b). Alkaline oxidation with CuO cleaves aryl ether bonds and releases phenolic monomers from the outer part of the lignin macromolecule that are indicative of lignin content and composition. The composition of lignin-derived 
phenols is characteristic of major plant groups because gymnosperm wood contains only vanillyl derivatives while angiosperm wood contains approximately equal quantities of vanillyls and syringyls (Hedges and Mann 1979). The non-woody vascular plant tissues of gymnosperms and angiosperms (e.g., conifer needles, grass and angiosperm leaves) contain cinnamyl units that are part of the lignin macromolecule or the ligno-cellulose complex (Lam et al. 2001). As such, the ratios of syringyl to vanillyl (S/V) and cinnamyl to vanillyl (C/V) monomers can be used to determine the botanical origin of lignin in soils and sediments (Ertel and Hedges 1984; Goñi et al. 2000; Otto and Simpson 2006b; Prahl et al. 1994). In addition, a decrease in $\mathrm{S} / \mathrm{V}$ and $\mathrm{C} / \mathrm{V}$ ratios can be indicative of progressive lignin degradation (Hedges et al. 1988) because syringyls and cinnamyls preferentially degrade resulting in the relative enrichment of vanillyls (Otto and Simpson 2006b). Lignin oxidation is also reflected by elevated ratios of lignin-derived phenolic acids and their corresponding aldehydes (Ad/Al) of both vanillyl and syringyl units (Hedges et al. 1982) and these ratios have been commonly used as indicators of the level of lignin degradation in soils and sediments (Ertel and Hedges 1984; Goñi et al. 2000; Otto and Simpson 2006b). For $\mathrm{CuO}$ oxidation, the soil residues from base hydrolysis $(0.1-3 \mathrm{~g})$ were extracted with $1 \mathrm{~g}$ $\mathrm{CuO}, 100 \mathrm{mg}$ ammonium iron (II) sulfate hexahydrate $\left[\mathrm{Fe}\left(\mathrm{NH}_{4}\right)_{2}\left(\mathrm{SO}_{4}\right)_{2} \cdot 6 \mathrm{H}_{2} \mathrm{O}\right]$ and $15 \mathrm{ml}$ of $2 \mathrm{M}$ $\mathrm{NaOH}$ in Teflon-lined bombs at $170{ }^{\circ} \mathrm{C}$ for $2.5 \mathrm{~h}$. The extracts were acidified to $\mathrm{pH} 1$ with $6 \mathrm{M} \mathrm{HCl}$ and kept for $1 \mathrm{~h}$ at room temperature in the dark to prevent the polymerization of cinnamic acids. After centrifugation, the supernatants were liquid-liquid extracted (3x) with $30 \mathrm{ml}$ diethyl ether. The ether extracts were dried with anhydrous $\mathrm{Na}_{2} \mathrm{SO}_{4}$, concentrated by rotary evaporation, transferred to $2 \mathrm{ml}$ glass vials and dried under a $\mathrm{N}_{2}$ stream.

The soil extracts were re-dissolved in $\mathrm{CH}_{2} \mathrm{Cl}_{2}: \mathrm{MeOH}(1: 1 v / v)$ and aliquots (containing $\sim 1 \mathrm{mg}$ extracts) were derivatized for GC-MS analysis. Solvent extracts and $\mathrm{CuO}$ oxidation products were converted to trimethylsilyl (TMS) derivatives by reaction with $90 \quad \mu l \quad N, O$-bis(trimethylsilyl)trifluoroacetamide (BSTFA) and $10 \mu \mathrm{l}$ anhydrous pyridine for $1 \mathrm{~h}$ at $70{ }^{\circ} \mathrm{C}$. After 
cooling, $400 \mu \mathrm{l}$ of hexane was added to dilute the extracts. For fatty acid esterification, base hydrolysis products were first methylated by reacting with $500 \mu \mathrm{l}$ of $N, N$-dimethylformamide dimethyl acetal (2 $\mathrm{mEq} / \mathrm{ml}$ in pyridine) at $60{ }^{\circ} \mathrm{C}$ for $15 \mathrm{~min}$ (Thenot et al. 1972). After being evaporated to dryness under a $\mathrm{N}_{2}$ stream, the base hydrolysis products were silylated with BSTFA and anhydrous pyridine. For the solvent extracts lauric acid, trehalose and ergosterol (as TMS esters) were used as external standards along with tetracosane. Tricosanoic acid methyl ester was used as an external standard for the base hydrolysis products, while vanillic acid-TMS was used for the $\mathrm{CuO}$ oxidation products. External standards were used to avoid the co-elution of internal standards with other compounds which are extracted using these techniques. GC-MS analysis was performed on an Agilent $6890 \mathrm{~N}$ GC coupled to an Agilent 5973 quadrupole mass selective detector. Separation was achieved on a HP-5MS fused silica capillary column (30 m x $0.25 \mathrm{~mm}$ i.d., $0.25 \mu \mathrm{m}$ film thickness $)$ with helium as the carrier gas $(1.2 \mathrm{ml}$

$\min ^{-1}$ ). The GC operating conditions were as follows: $65^{\circ} \mathrm{C}$ (hold for $2 \mathrm{~min}$ ), increased from 65 to 300 ${ }^{\circ} \mathrm{C}$ (at a rate of $6{ }^{\circ} \mathrm{C} \min ^{-1}$ ) and held at $300{ }^{\circ} \mathrm{C}$ for $20 \mathrm{~min}$. The sample $(1 \mu \mathrm{l})$ was injected with a $2: 1$ split ratio using an Agilent 7683 autosampler with the inlet temperature set at $280{ }^{\circ} \mathrm{C}$. The mass spectrometer was operated in the electron ionization mode (EI) at $70 \mathrm{eV}$ and scanned from $\mathrm{m} / \mathrm{z} 50$ to 650 . Data were acquired and processed with the Chemstation G1701DA software. Individual compounds were identified by comparison of mass spectra with published data, NIST98 and Wiley275 MS library data and authentic standards.

\subsection{Solid-state ${ }^{13}$ C nuclear magnetic resonance spectroscopy}

Solid-state ${ }^{13} \mathrm{C}$ NMR has been widely used to characterize SOM because it provides basic structural information on the whole soil sample (Kögel-Knabner 2000; Simpson et al. 2008; Simpson and Simpson 2012). The soil samples for solid-state ${ }^{13} \mathrm{C}$ Cross Polarization with Magic Angle Spinning (CP-MAS) NMR were repeatedly treated with $10 \%$ hydrofluoric acid to concentrate the organic matter 
and to remove paramagnetic minerals (Schmidt et al. 1997; Rumpel et al. 2006). The treated samples were rinsed with deionised water to remove excess salts and freeze-dried. Approximately $100 \mathrm{mg}$ of sample was packed into a $4 \mathrm{~mm}$ zirconium oxide rotor equipped with a Kel-F cap. The spectra were acquired on a $500 \mathrm{MHz}$ Bruker BioSpin Avance III spectrometer (Bruker BioSpin, Rheinstetten, Germany) equipped with a $4 \mathrm{~mm} \mathrm{H}-\mathrm{X}$ MAS probe, using a ramp-CP pulse program (Cardoza et al. 2004). The following acquisition parameters were employed: $13 \mathrm{kHz}$ spinning rate, $1 \mathrm{~ms}$ ramp-CP contact time and $1 \mathrm{~s}$ recycle delay. The spectra were processed using a zero filling factor of 2 and line broadening of $100 \mathrm{~Hz}$. The resulting NMR spectra were integrated into the following four chemical shift regions: alkyl carbon $(0-50 \mathrm{ppm})$ from methyl groups in alkyl chains and methylene carbons in lipids, waxes, cutin and/or suberin; $O$-alkyl carbon $(50-110 \mathrm{ppm})$ from carbon bonds and methoxy groups in carbohydrates and lignin; aromatic and phenolic carbon (110 - $165 \mathrm{ppm})$ from lignin, proteins and black carbon; carboxyl and carbonyl carbon (165-215 ppm) from fatty acids and peptides (Baldock et al. 1992; Simpson and Hatcher 2004; Simpson et al. 2008). All chemical shifts were calibrated using an external glycine standard and the total NMR signal $(0-215 \mathrm{ppm})$ was normalized to $100 \%$ to compare the relative contents of each type of carbon. The alkyl/O-alkyl ratio is often used as an indicator of the stage of degradation of SOM because $O$-alkyl compounds are labile and more easily degraded compared to alkyl compounds, resulting in increased ratios with progressive SOM degradation. The alkyl/O-alkyl ratios were calculated by dividing the areas of the alkyl and the $O$-alkyl regions of the NMR spectra (Baldock et al. 1992; Simpson et al. 2008).

\subsection{Data analyses}

A one-way analysis of variance (ANOVA) was applied using the Holm-Sidak multiple comparisons test for the determination of statistically significant differences $(P \leq 0.05)$ in SOM 
molecular composition between the native grassland/forest and the cultivated/pasture soil samples. Statistical analyses were performed using SigmaPlot version 11.0.

Changes in SOM compound classes with time since cultivation were calculated using the following equation:

$$
\text { Change }=([\mathrm{BC}]-[\mathrm{BN}]) /\left(\mathrm{t}_{2}-\mathrm{t}_{1}\right) \quad(\text { Equation } 1)
$$

where $[\mathrm{BC}]$ is the concentration of a particular compound class in the cultivated/pasture soils, [BN] is the concentration in the native grassland/forest soils, $\mathrm{t}_{2}$ is the year of sample collection (2000 or 2005) and $t_{1}$ is the year that the site was converted to the current land-use (Table 1).

\section{Results}

\subsection{Soil organic matter biomarkers}

The native and cultivated soils collected along the MAT gradient were different in terms of texture, $\mathrm{pH}$, organic $\mathrm{C}$ content and $\mathrm{C} / \mathrm{N}$ ratios (Table 1). These parameters have been described and interpreted in previous studies (Janzen et al. 1998; Haddix et al. 2011 and references therein; Mitchell and Simpson, 2013; Otto et al. 2005; Salloum et al. 2000). They are included in the present study to assist in the interpretation of molecular-level data. The solvent-extractable compounds identified in the native and cultivated soil samples collected along the MAT gradient consisted of alkyl compounds ( $n$ alkanols, $n$-alkanoic acids and n-alkanes), cyclic compounds (steroids and triterpenoids), monoacylglycerides, phenols and carbohydrates (Supplementary Tables S1 and S2). In the native soils, the $n$-alkanols ranged from $\mathrm{C}_{16}$ to $\mathrm{C}_{32}$ with a $\mathrm{C}_{\max }$ at $\mathrm{C}_{26}$, except the soils from Colorado and Texas which had a $\mathrm{C}_{\max }$ at $\mathrm{C}_{18}$. The $n$-alkanoic acids ranged from $\mathrm{C}_{9}$ to $\mathrm{C}_{30}$ and also included some short-chain mono-unsaturated compounds. Most soils had a short-chain homologue as their $\mathrm{C}_{\max }\left(\mathrm{C}_{16}, \mathrm{C}_{16: 1}\right.$ or $\left.\mathrm{C}_{18: 1}\right)$ except for the soils from Alberta, North Dakota and Costa Rica which had a long-chain $\mathrm{C}_{\max }\left(\mathrm{C}_{24}\right.$ or 
$\mathrm{C}_{26}$ ). The $n$-alkanes comprised a small component of the alkyl compounds and only long-chain homologues, ranging from $\mathrm{C}_{24}$ to $\mathrm{C}_{33}$, were found. The distribution of alkyl components of the native soils showed no particular trend with MAT. The cyclic compounds identified in the native soils included sterols and triterpenoids (Table S1). The major sterols were campesterol, stigmasterol and $\beta$-sitosterol, which was the most abundant sterol in all the soils (Table S1). In addition to these phytosterols, cholesterol and ergosterol were also detected. The triterpenoids identified included $\alpha$ - and $\beta$-amyrin, lupeol and ursolic acid and were most abundant in the soils from the native forest sites. Other lipids detected included a $\mathrm{C}_{16}$ mono-unsaturated monoacylglyceride and the phenol ferulic acid. The carbohydrates identified include glucose, mannose, sucrose and the disaccharide trehalose. The highest amount of carbohydrates was found in the Texas and Brazil soils. However, the distribution of these compounds showed no clear trend with MAT.

In the cultivated soils (Table S2), the $n$-alkanols ranged from $\mathrm{C}_{16}$ to $\mathrm{C}_{30}$ and generally had a short-chain $\mathrm{C}_{\max }\left(\mathrm{C}_{18}\right)$. The soils from the two colder sites (Melfort and Indian Head, Saskatchewan) and the soil from Costa Rica had a long-chain $\mathrm{C}_{\max }\left(\mathrm{C}_{28}\right.$ or $\left.\mathrm{C}_{26}\right)$. The $n$-alkanoic acids ranged from $\mathrm{C}_{14}$ to $\mathrm{C}_{28}$ with a $\mathrm{C}_{\max }$ at $\mathrm{C}_{16}$ for all the soils except the North Dakota $\left(\mathrm{C}_{24}\right)$ and the Texas soil $\left(\mathrm{C}_{16: 1}\right)$. The $n$ alkanes were a small component of the solvent extracts of the cultivated soils and only long-chain compounds were found $\left(\mathrm{C}_{24}-\mathrm{C}_{31}\right)$. The identified cyclic compounds include sterols and triterpenoids. As in the case of the native soils, the cultivated soils were dominated by plant-derived sterols and $\beta$ sitosterol was the most abundant sterol in all the soils except Brazil which was dominated by stigmasterol. Triterpenoids were only detected in the Indian Head-Saskatchewan and Costa Rica cultivated soils which were dominated by $\alpha$-amyrin and ursolic acid, respectively. Small amounts of the $\mathrm{C}_{16: 1}$ monoacylglyceride and the phenolic compound ferulic acid were detected in some soils. Carbohydrates, including glucose, mannose and sucrose, were most abundant at the warmest site 
(Brazil), but showed no clear trend with MAT. The disaccharide trehalose was most abundant in the soil from Brazil.

The relative abundance of microbial (short-chain saturated and unsaturated alkyl compounds $(<$ $\mathrm{C}_{20}$ ); the sterols cholesterol and ergosterol) and plant-derived (long-chain alkyl compounds $\left(\geq \mathrm{C}_{20}\right.$ ); the sterols campesterol, stigmasterol and $\beta$-sitosterol; the triterpenoids $\beta$ - and $\alpha$-amyrin, lupeol and ursolic acid; ferulic acid) solvent-extractable compounds was calculated in relation to the total concentration of free lipids measured in the native and cultivated soils (Figure 1). The native soils are dominated by plant-derived compounds (Figure 1) although there is no significant trend with increasing MAT $\left(\mathrm{r}^{2}=\right.$ $0.18 ; P=0.34)$. The relative abundance of microbial-derived compounds showed a slight increasing trend with increasing MAT $\left(\mathrm{r}^{2}=0.37 ; P=0.15\right)$ and a significantly higher relative abundance of microbial-derived compounds was found in the native soils with higher MAT $(P \leq 0.05$; Figure 1$)$. The cultivated soils are also dominated by plant-derived compounds with the exception of the Texas soil which has equal amounts of microbial and plant-derived SOM and the Brazil soil which is dominated by microbial-derived material. The relative abundance of microbial-derived compounds typically increases from the native to the cultivated soils and shows a larger increase at warmer temperatures (up to $17 \%$ increase). The relative abundance of plant-derived compounds typically decreases from the native to the cultivated soils, with the largest decrease occurring between the Alberta (native) and Melfort (cultivated) soils (up to $64 \%$ decrease).

The difference in microbial and plant-derived solvent-extractable compounds since the year of land conversion was calculated and used as an estimate for the rate of SOM decomposition or accumulation (Equation 1). On a per year basis, the solvent-extractable microbial-derived components generally decreased with cultivation (Figure 2a). At the cooler sites (Alberta and Indian HeadSaskatchewan) and at the warmest site (Brazil), microbial-derived SOM components increased with cultivation. The solvent-extractable plant-derived SOM also decreased from the time of land-use 
conversion (with the only exception of Indian Head-Saskatchewan) and the warmest sites showed the largest decreases of plant-derived SOM. The variation in the response of compound classes in the soils collected along the MAT gradient are likely due to the different agricultural management practices which vary in disturbance type.

The major compound classes identified in the base hydrolysis extracts of the native and cultivated soils collected along the MAT gradient consisted of alkyl compounds ( $n$-alkanols, $n$-alkanoic acids, branched $n$-alkanoic acids, $n$-alkane- $\alpha, \omega$-dioic acids, $\omega$-hydroxyalkanoic acids, $\alpha$-hydroxyalkanoic acids and mid-chain hydroxy and epoxy acids) and small amounts of benzyls, phenols and steroids (Supplementary Tables S3 and S4). The most abundant alkyl components in the native soils were generally the $n$-alkanoic acids which ranged from $\mathrm{C}_{12}$ to $\mathrm{C}_{32}$ and had a low molecular weight $\mathrm{C}_{\max }\left(\mathrm{C}_{16}\right.$ or $\mathrm{C}_{18: 1}$ ). The native soils from cooler sites, Alberta and Indian Head-Saskatchewan, had a $\mathrm{C}_{\max }$ at $\mathrm{C}_{28}$ and $\mathrm{C}_{24}$, respectively. Short-chain branched $n$-alkanoic acids (iso- and anteiso- $\mathrm{C}_{16}$ and $\mathrm{C}_{18}$ ) were detected in all the native soils and were most abundant in the sample from Colorado. The $n$-alkane- $\alpha, \omega-$ dioic acids ranged from $\mathrm{C}_{16}$ to $\mathrm{C}_{28}$ with a long-chain $\mathrm{C}_{\max }\left(\mathrm{C}_{22}, \mathrm{C}_{24}\right.$ or $\left.\mathrm{C}_{26}\right)$ at all the sites except at the two warmer sites, Costa Rica and Brazil, which had a short-chain $\mathrm{C}_{\max }\left(\mathrm{C}_{16}\right)$. The $\omega$-hydroxyalkanoic acids ranged from $\mathrm{C}_{16}$ to $\mathrm{C}_{26}$ and typically had a long-chain $\mathrm{C}_{\max }\left(\mathrm{C}_{24}\right.$ or $\left.\mathrm{C}_{26}\right)$. A short-chain $\mathrm{C}_{\max }\left(\mathrm{C}_{16: 1}\right)$ was observed for the North Dakota, Costa Rica and Brazil soils. Mid-chain hydroxy acids were most abundant in the warmer, native forest soils and their distribution was dominated by 7- or 8-hexadecane1,16-dioic acid in Costa Rica and dihydroxy-methoxyoctadecanoic acid in Brazil. These compounds were found either at low concentration or were not detected in the low MAT native grassland soils. The observed benzyls and phenols were major components of the native soil base extracts (Table S3).

The cultivated soils were dominated by $n$-alkanoic acids ranging from $C_{12}$ to $C_{32}$ and a shortchain $\mathrm{C}_{\max }\left(\mathrm{C}_{16}\right.$ or $\left.\mathrm{C}_{18: 1}\right)$. Branched alkanoic acids of microbial origin ranged from $\mathrm{C}_{15}$ to $\mathrm{C}_{18}$ and were detected in all the cultivated soils except North Dakota. The $n$-alkane- $\alpha, \omega$-dioic acids ranged from $\mathrm{C}_{16}$ to 
$\mathrm{C}_{28}$ and had a long-chain $\mathrm{C}_{\max }\left(\mathrm{C}_{22}\right.$ or $\left.\mathrm{C}_{24}\right)$, except the soil from Brazil which had a short-chain $\mathrm{C}_{\max }$ $\left(\mathrm{C}_{16}\right)$. The $\omega$-hydroxyalkanoic acids ranged from $\mathrm{C}_{16}$ to $\mathrm{C}_{26}$ and typically had a long-chain $\mathrm{C}_{\max }\left(\mathrm{C}_{22}, \mathrm{C}_{24}\right.$ or $\left.\mathrm{C}_{26}\right)$ except for the Indian Head-Saskatchewan cultivated soil $\left(\mathrm{C}_{18: 1}\right)$ and the soils from Texas and Brazil $\left(\mathrm{C}_{16: 1}\right)$. As in the case of the native soils, mid-chain hydroxy acids were most abundant in the cultivated soils from the warmer sites. Benzyl compounds were typically not very abundant in the cultivated soils while phenols were most abundant in soils from the warmer sites.

Based on the suberin to cutin ratio $(\mathrm{S} / \mathrm{C})$, the cooler, native grassland soils are dominated by root inputs, except for the Alberta soil which had a lower S/C value (Figure 3a). The warmer, native forest soils from Costa Rica and Brazil have the lowest S/C ratios, indicating dominant inputs from leaf cuticles. Upon cultivation, the S/C ratio generally increased (up to $94 \%$ at the North Dakota site) suggesting either a change from aboveground to belowground inputs or enhanced degradation of cutin. At the Indian Head-Saskatchewan and Colorado sites, the cultivated soils had a lower S/C ratio compared to the native soils (up to $49 \%$ decrease). For both the native and cultivated soils, the $\mathrm{S} / \mathrm{C}$ ratio showed a linear decrease with increasing MAT despite their different mineralogy and other environmental characteristics. For the native and cultivated soils (Figure $3 b$ ) the lower $\omega-\mathrm{C}_{16} / \Sigma \mathrm{C}_{16}$ values obtained for the soils at the warmer sites may indicate fresh cutin inputs. Generally, the native soils had a higher $\omega-\mathrm{C}_{16} / \Sigma \mathrm{C}_{16}$ ratio compared to the cultivated soils, suggesting a more degraded state of the cutin in the native soils. This trend may be the result of continuous fresh cutin inputs from crop rotation at the cultivated sites. At the two warmer sites, the difference in cutin degradation between the native and cultivated soils is much smaller (up to $6 \%$ increase in the $\omega-\mathrm{C}_{16} / \Sigma \mathrm{C}_{16}$ ratio) than at the colder sites and likely due to the longer growing seasons. The ester-bound suberin-derived compounds decreased at some of the grassland sites (Indian Head-Saskatchewan, Colorado and Texas) since the year of land-use conversion (Figure 2b) while these compounds increased at one grassland site (North Dakota) and at the two warmer sites (Costa Rica and Brazil). Relatively small changes were observed in 
cutin-derived compounds except at the two warmer sites where cutin-derived compounds decreased, likely due to changes in vegetation and a shift from aboveground to belowground inputs.

Upon $\mathrm{CuO}$ oxidation, eight lignin-derived phenols were released and identified which belonged to the vanillyl (vanillin, acetovanillone and vanillic acid), syringyl (syringaldehyde, acetosyringone and syringic acid) and cinnamyl ( $p$-coumaric acid and ferulic acid) groups (Supplementary Table S5). The native soils are dominated by vanillyl-type monomers, except for the North Dakota soil which is dominated by syringyl-type units. The total amount of lignin-derived phenols did not show an increasing trend with MAT $\left(r^{2}=0.02 ; P=0.73\right)$. In the cultivated soils, the most abundant lignin monomers were generally the syringyl units. As in the case of the native soils, the total lignin phenols did not show an increasing trend with MAT $\left(\mathrm{r}^{2}=0.20 ; P=0.33\right)$. Overall, the lignin-derived phenols decreased in most of the soils since the year of land-use conversion (Figure 2c) with vanillyl monomers decreasing to a greater extent than cinnamyl and syringyl monomers. In the Texas and Brazil soils, syringyl units increased while cinnamyl units increased in the three warmer soils.

A plot of S/V and C/V (Figure 4a) shows differences between lignin residues in grassland and forest sites. The native grassland sites have significantly higher $\mathrm{C} / \mathrm{V}$ ratios $(P \leq 0.05$; Table S5) compared to the native forest soils which are clearly dominated by gymnosperm inputs. Similarly, the $\mathrm{S} / \mathrm{V}$ values are significantly higher at the northern grassland sites $(P \leq 0.05$; Table $\mathrm{S} 5)$ compared to the forest soils. In addition to lignin sources, phenolic monomers were used to determine changes in lignin oxidation along the MAT gradient and with soil cultivation. A plot of Ad/Al ratios for the native and cultivated soils (Figure 4b) shows that the native grassland soils from the colder sites (Alberta, Indian Head-Saskatchewan and North Dakota) had the highest $(\mathrm{Ad} / \mathrm{Al})_{\mathrm{v}}$, indicating the highest degree of lignin oxidation. Elevated $(\mathrm{Ad} / \mathrm{Al})_{\mathrm{s}}$ ratios were also observed for native soils at colder MAT. However, there was no significant trend between lignin oxidation and MAT $\left(\mathrm{r}^{2}=0.55 ; P=0.06\right)$. Generally speaking, 
the lignin from the cultivated soils is at a more advanced stage of oxidation compared to the native soils as indicated by elevated $\mathrm{Ad} / \mathrm{Al}$ ratios of both syringyl and vanillyl units (Figure 4b).

\subsection{Solid-state ${ }^{13}$ C nuclear magnetic resonance spectroscopy}

The solid-state ${ }^{13} \mathrm{C}$ NMR spectra (examples in Figure 5) and integration results (Table 2) identified different SOM components in the native and cultivated soil samples collected along the MAT gradient. The native soils are dominated by $O$-alkyl structures except the Alberta native soil which has equal quantities of $O$-alkyl and aromatic and phenolic carbon, and the native soil from Brazil which is dominated by alkyl components. No trend was found between the different carbon moieties of the bulk SOM and MAT for the native soils. The cultivated soils are also dominated by $O$-alkyl carbon structures except for the cultivated Texas soil which is dominated by alkyl components. Again, no significant trend was found between the different carbon moieties of the cultivated soils and MAT. The native forest soil from Brazil and the cultivated Texas soil had the highest alkyl/O-alkyl ratios, indicating the presence of bulk SOM that is at a more advanced stage of degradation compared to the other soils (Table 2). No significant trend was observed in the alkyl/O-alkyl ratio of the native or cultivated soils with increasing MAT.

The relative abundance of the alkyl components of the bulk SOM obtained using ${ }^{13} \mathrm{C}$ NMR decreased since the year of land-use conversion at all the sites except for the Texas soil (Figure 2d). The change in the relative abundance of $O$-alkyl components showed no apparent trend with increasing MAT and showed the largest increase at the Brazil site and the largest decrease at the Texas site. The relative abundance of the aromatic and phenolic carbon moieties in the bulk SOM also showed no trend with increasing MAT, but showed the largest increase in the Texas soil and the largest decrease in the North Dakota soil. Finally, the relative abundance of the carbonyl and carboxyl carbon moieties increased at all the sites, except in Texas and Brazil. 


\section{Discussion}

\subsection{Soil organic matter composition with increasing MAT}

The native soils vary in characteristics such as texture, $\mathrm{pH}$, organic $\mathrm{C}$ content and $\mathrm{C}: \mathrm{N}$ ratios (Table 1). While these characteristics provide general information on SOM quality and quantity, a more detailed characterization, through the molecular identification of source-specific biomarkers provided valuable information on SOM changes associated with MAT and land-use change. Proteins and carbohydrates are generally considered to be more easily degradable compared to macromolecular lipids and aromatic structures (Melillo et al. 1982). The carbohydrates identified in this study are of both plant and microbial origin and did not follow any significant trend with increasing MAT (Table S1), in agreement with the NMR $O$-alkyl signal (Table 2). However, there was no significant relationship between the relative contribution of $O$-alkyl components and the soil active fraction previously measured on these same soils (SOC respired; Table 2; Haddix et al. 2011), suggesting that not all of the $O$-alkyl components are labile and may derive from plant material that is protected within aggregates or by the mineral matrix as in the allophanic soil from Costa Rica. In addition to signals from carbohydrates and peptides, the NMR $O$-alkyl region also includes signals from methoxy groups in lignin ( $56 \mathrm{ppm})$, causing its signal to be more abundant than the total percent of carbohydrates, peptides and N-containing compounds previously obtained using Pyrolysis-Molecular Beam Mass Spectrometry (Py-MBMS; Table 2; Haddix et al. 2011). However, a significant correlation $\left(\mathrm{r}^{2}=0.76 ; P\right.$ $<0.05)$ was observed between the relative contribution of $O$-alkyl carbon to the NMR spectrum and the sum of carbohydrates, peptides and N-containing compounds detected with Py-MBMS (Figure S1) indicating that the two techniques are comparable.

Due to its large macromolecular structure, lignin was originally believed to be stable in soils (Kögel-Knabner 2002; Melillo et al. 2002), but studies have shown that lignin is indeed susceptible to 
soil priming brought on by increased soil temperatures (Feng et al. 2008; Pisani et al. 2015; Stevenson 1982). In the native soils, the variation in the total amount of vanillyl, syringyl or cinnamyl phenols with MAT (Table S5) may be attributed to factors other than climate (e.g., the soil microbial community and soil moisture) or to a different lignin signature in the residues of plant tissues along the MAT gradient. However, no significant correlations were found between the soil lignin content and soil mineralogy $(\%$ sand, silt or clay) and $\mathrm{pH}$. The cinnamyl monomers that are abundant in non-woody vascular plant tissues of grasses and angiosperm leaves (Lam et al. 2001) increased significantly with MAT only in the native grassland sites (Table S5; $\mathrm{r}^{2}=0.87, P \leq 0.05$ ), suggesting increased plant productivity at warmer temperatures. Lignin oxidation in the form of $\mathrm{Ad} / \mathrm{Al}$ ratios and the intensity of the aromatic and phenolic NMR signal did not show any significant trend with increasing MAT (Table 2, Figure 4b), suggesting that temperature alone does not control the preservation and degradation of these compounds and that there may be other environmental factors involved in the stabilization of lignin in soils (Pisani et al. 2014; Thevenot et al. 2010). Because lignin degradation was also not significantly correlated with soil mineralogy or $\mathrm{pH}$, other environmental factors may be more important for lignin stabilization. In another study, grassland soils collected along a MAT gradient showed a decreasing degree of lignin degradation with increasing MAT and this was attributed to a lack of additional carbon sources, such as saccharides and root litter, which are needed for the co-metabolic biodegradation of lignin (Amelung et al. 1999). The soil nitrogen content can have a variable influence on lignin degradation as a function of local environmental conditions (Thevenot et al. 2010). Lignin oxidation may also be enhanced by abiotic mechanisms such as photo-degradation (Feng et al. 2011) which should be enhanced in grassland soils due to the lack of shading from trees. Freezing and thawing cycles may also play a role in lignin oxidation (Feng et al. 2007), especially in the cooler soils that regularly undergo repeated freezing and thawing. 
Alkyl SOM structures that are abundant in the cuticles of plant leaves and the suberin of roots (Kolattukudy 1980; Lorenz et al. 2007) are believed to be relatively stable and have been shown to accumulate in various types of soils (Feng et al. 2008; Lorenz et al. 2007; Nierop 1998; Pisani et al. 2014; Riederer et al. 1993). The stability of these compounds in soil is typically attributed to their inherent molecular structure (Lorenz et al. 2007; Pisani et al. 2014) although their interactions with mineral surfaces through the selective sorption of polymethylene carbon (Feng et al. 2005; Lin and Simpson, 2016) and the preferential preservation of root- versus leaf-derived lipids in soils (Mueller et al. 2013) have also been reported. The S/C ratio of the soils showed a linear decrease with increasing MAT (Pisani et al. 2014) despite the different mineralogy and other environmental characteristics, suggesting that these soils may share a common set of ecological mechanisms that govern some of their biogeochemical processes (Fierer et al. 2009). Long-chain alkyl components in the soils collected along this same MAT gradient were found to accumulate with increasing MAT (Pisani et al. 2014). Due to a lack of correlation with the soil clay content and soil $\mathrm{pH}$, this trend was attributed to the inherent chemical recalcitrance of these alkyl structures and to the preferential degradation of other SOM components (Pisani et al. 2014). However, it has been suggested that molecular structure alone does not control SOM stability and that this process should be viewed as an ecosystem property controlled by multiple environmental factors (Schmidt et al. 2011).

\subsection{Preservation and degradation of SOM components with soil cultivation}

Measurement of the SOC contents (Table 1) reveals that cultivation reduced between 10 and 42 $\%$ of the original carbon present in virgin, uncultivated soils. The average of $26 \%$ determined for this study is very similar to that quoted by Davidson and Ackerman (1993) and may contribute significantly to $\mathrm{CO}_{2}$ release to the atmosphere on a global scale (Cole et al. 1997). Changes in land-use may increase the total soil microbial biomass and shift the community structure toward a fungal-dominated 
community, enhancing the accumulation of microbial-derived organic matter (Six et al. 2006). In this study, the relative abundance of microbial-derived solvent-extractable SOM components (short-chain alkyl compounds and microbial sterols) significantly increased with cultivation at warmer temperatures (Figure 1). This was also the case on a per year basis (Figure 2a) where microbial-derived compounds showed the largest increase at the warmest site. A shift towards microbial-derived SOM components with cultivation was also observed by a change in $\mathrm{C}_{\max }$ values from long-chain to short-chain alkyl compounds (Tables S1 and S2). This large increase in microbial components may be related to the higher concentration of ergosterol, a signature lipid for soil fungi (Ruzicka et al. 2000) which have been suggested to contribute to enhanced carbon sequestration in agricultural soils (Six et al. 2006). The concentration of microbial components along the studied transect suggest that agricultural management practices differ in the type and intensity of disturbance, varying the impact on microbial biomass and microbial-derived SOM depending on the management practice employed (Plaza et al. 2013; Six et al. 2006). In addition, the degree to which microbial-derived organic matter is protected from decomposition in soil depends on their interaction with the soil mineral matrix and physical occlusion within stable soil aggregates (Six et al. 2000).

Cultivated soils generally show a lower contribution of plant-derived SOM components compared to native soils (Nierop et al. 2001; Quénéa et al. 2006) likely due to changes in vegetation, soil aggregate disruption and other disturbances associated with management practices (Elliott 1986; Paul et al. 2004). The soil fraction that is typically associated with plant-derived material (> $250 \mu \mathrm{m})$ has been shown to be significantly reduced in cultivated soils collected along our same MAT transect, particularly at the colder grassland sites (Table S6). In the present study, the solvent-extractable plantderived SOM decreased from the time of land-use conversion (with the only exception of Indian HeadSaskatchewan) and the warmest sites showed the largest decreases of plant-derived SOM (Figure 2a). Two of the major plant-derived SOM structural classes found in soils are the aromatic structures of 
lignin and the alkyl structures of plant waxes, cutin and suberin (Kögel-Knabner 2002; Lorenz et al. 2007). Lignin has long been suspected to contribute to the stable carbon pool in soils (Kögel-Knabner 2002; Melillo et al. 2002; Waksman 1929), but studies have suggested that it may be degraded in agricultural soils (Kiem and Kögel-Knabner 2003; Lobe et al. 2002; Stevenson 1982). In agreement with a previous study (Lobe et al. 2002) the total lignin content was higher in the native grassland compared to the cultivated soils (Table S5), suggesting enhanced lignin degradation with land-use. Lignin oxidation may be favored with cultivation practices that result in aggregate disruption and degradation of particulate organic matter (Elliott 1986; Paul et al. 2006). This is also shown by the higher Ad/Al ratios of both syringyl and vanillyl phenols of the cultivated soils (Figure 4b). This was particularly the case at the warmer sites where the conversion of land from forest to pasture resulted in loss of shade and likely enhancement of lignin photo-degradation.

The contribution of the alkyl structures of cutin and suberin to SOM in cultivated soils can help elucidate the fate of above- and belowground biomass because agricultural crops have much less suberized aboveground tissues compared to woody plants (Mendez-Millan et al. 2010). In this study, soil cultivation significantly increased the S/C ratio with the exception of the Colorado site (Figure 3a). In addition to possible changes in SOM inputs, the higher suberin content may be due to the better preservation of suberin compared to cutin compounds because suberin contains phenolic units and is embedded in root and bark tissues (Riederer et al. 1993). A significant decrease in suberin was observed in the Indian Head-Saskatchewan and Colorado cultivated soils (Figure 2b) likely due to the particular land management practices at those sites (crop rotation and tillage; Table 1). Continuous tillage can result in soil aggregate disruption (Elliott 1986; Paul et al. 2004) and enhance the availability of some SOM components. Cultivation resulted in cutin degradation (elevated $\omega-\mathrm{C}_{16} / \Sigma \mathrm{C}_{16}$ ratio) and was most pronounced in the Alberta, Indian Head-Saskatchewan and Texas soils (Figure 3b). The differences in cutin degradation observed between sites are likely due to the varying stability of these structures in 
soils (Lorenz et al. 2007) or to the continuous input of fresh cutin compounds due to crop rotation. On a per year basis, the total amount of cutin decreased only at the two forest sites that were converted to pasture (Figure 2b). This is in agreement with the reduction of the alkyl carbon NMR signal (Figure 2d) and suggests that cutin may be susceptible to degradation with cultivation of land.

\section{Conclusions}

The combined use of molecular-level methods of native and cultivated soils collected along a MAT gradient revealed differences in molecularly distinct SOM components to both increasing temperature and land-use change. The variability of responses for carbohydrates and lignin to increasing MAT in the native grassland and forest soils may be attributed to other factors (e.g., the soil microbial community, moisture regime, litter quality and quantity as well as land-use). However, alkyl components from native soils collected along the same MAT gradient were found to accumulate with increasing MAT likely due to the inherent chemical recalcitrance or interactions with other soil components, such as clay mineral surfaces or other SOM constituents (Pisani et al., 2014; Feng et al., 2005; Clemente and Simpson, 2013). Increased microbial inputs and enhanced lignin degradation were the main shifts in SOM composition observed in the cultivated soils with both processes likely influenced by different site management practices (e.g., crop rotation and tillage, crop species and productivity). Soil cultivation also resulted in changes from aboveground to belowground inputs (elevated S/C ratios) and enhanced cutin degradation. These results suggest that long-term cultivation and the application of different agricultural management practices may decrease more stable SOM components, such as cutin. This carbon fraction typically accounts for a major portion of the total soil carbon pool ( $\mathrm{Li}$ et al. 2013) suggesting that cutin-derived SOM may become a source of atmospheric $\mathrm{CO}_{2}$ with increases in land-use change. Although our study included many soil samples collected along a bi-continental transect, future research should test the observations reported here using a wider sample 
range. The overarching implications of this work suggest that environmental factors, namely climate, coupled with land conversion from native to cultivated soils may decrease forms of SOM that have been previously considered to be resistant to both climate change impacts and agricultural practices.

\section{Acknowledgements}

The Natural Science and Engineering Research Council (NSERC) of Canada provided funding for this research via a Discovery Grant and a Discovery Accelerator Supplement to MJS. The research also was supported by The Office of Science (BER), US Department of Energy and the National Science foundation (DEB-0444880). We also thank Katherine M. Hills for conducting biomarker experiments and Dr. Denis Courtier-Murias for assistance with NMR data acquisition.

\section{References}

Amelung W, Flach KW, Zech W (1999) Lignin in particle-size fractions of native grassland soils as influenced by climate. Soil Sci Soc Am J 63:1222-1228

Bahri H, Dignac MF, Rumpel C, Rasse DP, Chenu C, Mariotti A (2006) Lignin turnover kinetics in an agricultural soil is monomer specific. Soil Biol Biochem 38:1977-1988

Baldock JA, Oades JM, Waters AG, Peng X, Vassallo AM, Wilson MA (1992) Aspects of the chemical structure of soil organic materials as revealed by solid-state ${ }^{13} \mathrm{C}$ NMR spectroscopy. Biogeochemistry 16:1-42

Batjes NH (1996) Total carbon and nitrogen in the soils of the world. Eur J Soil Sci 47:151-163

Bianchi G (1995) Plant waxes. In: Hamilton RJ (ed) Waxes: Chemistry, molecular biology and functions. The Oily Press, Dundee, pp 175-222

Bull ID, Nott CJ, van Bergen PF, Poulton PR, Evershed RP (2000) Organic geochemical studies of soils from the Rothamsted classical experiments. VI. The occurrence and source of organic acids in an experimental grassland soil. Soil Biol Biochem 32:1367-1376

Cardoza LA, Korir AK, Otto WH, Wurrey CJ, Larive CK (2004) Applications of NMR spectroscopy in environmental science. Prog Nucl Magn Res Spectrosc 45:209-238

Clemente, JS, Simpson, MJ (2013) Physical protection of lignin by organic matter and clay minerals from chemical oxidation. Org Geochem 58:1-12

Cole CV, Duxbury J, Freney J, Heinemeyer O, Minami K, Mosier A, Paustian K, Rosenberg N, Sampson N, Sauerbeck D, Zhao Q (1997) Global estimates of potential mitigation of greenhouse gas emissions by agriculture. Nutr Cycl Agroecosyst 49:221-228

Conant RT, Easter M, Paustian K, Swan A, Williams S (2007) Impacts of periodic tillage on soil C stocks: A synthesis. Soil Tillage Res 95:1-10

da Silva Oliveira DM, Schellekens, J, Cerri CEP (2016) Molecular characterization of soil organic matter from native vegetation-pasture-sugarcane transitions in Brazil. Sci Total Environ 548549:450-462

Davidson EA, Ackerman IL (1993) Changes in soil carbon inventories following cultivation of previously untilled soils. Biogeochemistry 20:161-164 
Elliott ET (1986) Aggregate structure and carbon, nitrogen, and phosphorus in native and cultivated soils. Soil Sci Soc Amer J 50:627-633

Ertel JR, Hedges JI (1984) The lignin component of humic substances: distribution among soil and sedimentary humic, fulvic, and base-insoluble fractions. Geochim Cosmochim Acta 48:2065-2074

Feng X, Simpson AJ, Simpson MJ (2005) Chemical and mineralogical controls on humic acid sorption to clay mineral surfaces. Org Geochem 36:1553-1566

Feng X, Nielsen LL, Simpson MJ (2007) Responses of soil organic matter and microorganisms to freeze-thaw cycles. Soil Biol Biochem 39:2027-2037

Feng X, Simpson AJ, Wilson KP, Williams DD, Simpson MJ (2008) Increased cuticular carbon sequestration and lignin oxidation in response to soil warming. Nat Geosci 1:836-839

Feng X, Simpson MJ (2011) Molecular-level methods for monitoring soil organic matter responses to global climate change. J Environ Monit 13:1246-1254

Feng X, Hills KM, Simpson AJ, Whalen JK, Simpson MJ (2011) The role of biodegradation and photooxidation in the transformation of terrigenous organic matter. Org Geochem 42:262-274

Fierer N, Grandy SA, Six J, Paul EA (2009) Searching for unifying principles in soil ecology. Soil Biol Biochem 41:2249-2256

Frey SD, Lee J, Melillo JM, Six J (2013) The temperature response of soil microbial efficiency and its feedback to climate. Nat Clim Change 3:395-398

Goñi MA, Hedges JI (1990a) Cutin-derived CuO reaction products from purified cuticles and tree leaves. Geochim Cosmochim Acta 54:3065-3072

Goñi MA, Hedges JI (1990b) The diagenetic behavior of cutin acids in buried conifer needles and sediments from a coastal marine environment. Geochim Cosmochim Acta 54:3083-3093

Goñi MA, Yunker MB, Macdonald RW, Eglinton TI (2000) Distribution and sources of organic biomarkers in arctic sediments from the Mackenzie River and Beaufort Shelf. Mar Chem 71:23-51

Haddix ML, Plante AF, Conant RT, Six J, Steinweg JM, Magrini-Bair K, Drijber RA, Morris SJ, Paul EA (2011) The role of soil characteristics on temperature sensitivity of soil organic matter. Soil Sci Soc Am J 75:56-68

Hartmann MA (1998) Plant sterols and the membrane environment. Trends Plant Sci 3:170-175

Harwood JL, Russell NJ (1984) Lipids in plants and microbes. George Allen and Unwin, London

Hedges JI, Mann DC (1979) The characterization of plant tissues by their lignin oxidation products. Geochim Cosmochim Acta 43:1803-1807

Hedges JI, Ertel JR, Leopold EB (1982) Lignin geochemistry of a Late Quaternary sediment core from Lake Washington. Geochim Cosmochim Acta 46:1869-1877

Hedges JI, Blanchette RA, Weliky K, Devol AH (1988) Effects of fungal degradation on the CuO oxidation products of lignin: A controlled laboratory study. Geochim Cosmochim Acta 52:27172726

Huang Z, Clinton PW, Davis MR (2011) Post-harvest residue management effects on recalcitrant carbon pool and plant biomarkers within the soil heavy fraction in Pinus radiata plantations. Soil Biol Biochem 43:404-412

IPCC (2007) Climate Change 2007: Synthesis Report. An Assessment of the Intergovernmental Panel on Climate Change. Valencia, Spain

Janzen HH, Campbell CA, Izaurralde RC, Ellert BH, Juma N, McGill WB, Zentner RP (1998) Management effects on soil C storage on the Canadian prairies. Soil Till Res 47:181-195

Kiem R, Kögel-Knabner I (2003) Contribution of lignin and polysaccharides to the refractory carbon pool in C-depleted arable soils. Soil Biol Biochem 35:101-118

Kögel-Knabner I (2000) Analytical approaches for characterizing soil organic matter. Org Geochem 31:609-625 
Kögel-Knabner I (2002) The macromolecular organic composition of plant and microbial residues as inputs to soil organic matter. Soil Biol Biochem 34:139-162

Kögel-Knabner I, Ziegler F, Riederer M, Zech W (1989) Distribution and decomposition pattern of cutin and suberin in forest soils. Z Pflanzenernähr Bodenkd 152:409-413

Koide RT, Shumway DL, Stevens CM (2000) Soluble carbohydrates of red pine (Pinus resinosa) mycorrhizas and mycorrhizal fungi. Mycol Res 104:834-840

Kolattukudy PE (1980) Biopolyesters of plants: Cutin and suberin. Science 208:990-1000

Lal R (2004) Soil carbon sequestration impacts on global climate change and food security. Science 304:1623-1627

Lam TBT, Kadoya K, Iiyama K (2001) Bonding of hydrocinnamic acids to lignin: ferulic and $p$ coumaric acids are predominantly linked at the benzyl position of lignin, not the $\beta$-position, in grass cell walls. Phytochemistry 57:987-992

Li D, Schädel C, Haddix ML, Paul EA, Conant R, Li J, Zhou J, Luo Y (2013) Differential responses of soil organic carbon fractions to warming: Results from an analysis with data assimilation. Soil Biol Biochem 67:24-30

Lichtfouse E, Berthier G, Houot S, Barriuso E, Bergheaud V, Vallaeys T (1995) Stable carbon isotope evidence for the microbial origin of $\mathrm{C}_{14}-\mathrm{C}_{18} n$-alkanoic acids in soils. Org Geochem 23:849-852

Lin, LH, Simpson, MJ (2016) Enhanced extractability of cutin- and suberin-derived organic matter with demineralization implies physical protection over chemical recalcitrance in soil. Org Geochem 97:111-121

Lobe I, Du Preez CC, Amelung W (2002) Influence of prolonged arable cropping on lignin compounds in sandy soils of the South African Highveld. Eur J Soil Sci 53:553-562

Lorenz K, Lal R, Preston CM, Nierop KGJ (2007) Strengthening the soil organic carbon pool by increasing contributions from recalcitrant bio(macro)molecules. Geoderma 142:1-10

Medeiros PM, Simoneit BRT (2007) Gas chromatography coupled to mass spectrometry for analyses of organic compounds and biomarkers as tracers for geological, environmental, and forensic research. J Sep Sci 30:1516-1536

Melillo JM, Aber JD, Muratore JF (1982) Nitrogen and lignin control of hardwood leaf litter decomposition dynamics. Ecology 63:621-626

Melillo JM, Steudler PA, Aber JD, Newkirk K, Lux H, Bowles FP, Catricala C, Magill A, Ahrens T, Morrisseau S (2002) Soil warming and carbon-cycle feedbacks to the climate system. Science 298:2173-2176

Mendez-Millan M, Dignac MF, Rumpel C, Rasse DP, Derenne S (2010) Molecular dynamics of shoot vs. root biomarkers in an agricultural soil estimated by natural abundance ${ }^{13} \mathrm{C}$ labelling. Soil Biol Biochem 42:169-177

Mitchell PJ, Simpson MJ (2013) High affinity sorption domains in soil are blocked by polar soil organic matter components. Environ Sci Technol 47:412-419

Mueller KE, Eissenstat DM, Müller CW, Oleksyn J, Reich PB (2013) What controls the concentration of various aliphatic lipids in soil? Soil Biol Biochem 63:14-17

Nierop KGJ (1998) Origin of aliphatic compounds in a forest soil. Org Geochem 29:1009-1016

Nierop KGJ, Pulleman MM, Marinissen JCY (2001) Management induced organic matter differentiation in grassland and arable soil: A study using pyrolysis techniques. Soil Biol Biochem 33:755-764

Otto A, Simpson MJ (2005) Degradation and preservation of vascular plant-derived biomarkers in grassland and forest soils from Western Canada. Biogeochemistry 74:377-409

Otto A, Shunthirasingham C, Simpson MJ (2005) A comparison of plant and microbial biomarkers in grassland soils from the Prairie Ecozone of Canada. Org Geochem 36:425-448

Otto A, Simpson MJ (2006a) Sources and composition of hydrolysable aliphatic lipids and phenols in soils from western Canada. Org Geochem 37:385-407 
Otto A, Simpson MJ (2006b) Evaluation of $\mathrm{CuO}$ oxidation parameters for determining the source and stage of lignin degradation in soil. Biogeochemistry 80:121-142

Otto A, Simpson MJ (2007) Analysis of soil organic matter biomarkers by sequential chemical degradation and gas chromatography-mass spectrometry. J Sep Sci 30:272-282

Paul EA, Morris SJ, Six J, Paustian K, Gregorich EG (2003). Interpretation of soil carbon and nitrogen dynamics in agricultural and afforested soils. Soil Sci Soc Am J 67:1620-1628

Paul EA, Collins HP, Paustian K, Elliott ET, Frey S, Juma N, Janzen H, Campbell CA, Zentner RP, Lafond GP, Moulin AP (2004) Management effects on the dynamics and storage rates of organic matter in long-term rotations. Can J Soil Sci 84:49-61

Pisani O, Hills KM, Courtier-Murias D, Haddix ML, Paul EA, Conant RT, Simpson AJ, Arhonditsis GB, Simpson MJ (2014) Accumulation of aliphatic compounds in soil with increasing mean annual temperature. Org Geochem 76:118-127

Pisani O, Frey SD, Simpson AJ, Simpson MJ (2015) Soil warming and nitrogen deposition alter soil organic matter composition at the molecular-level. Biogeochemistry 123:391-409

Plante AF, Fernández JM, Haddix ML, Steinweg JM, Conant RT (2011) Biological, chemical and thermal indices of soil organic matter stability in four grassland soils. Soil Biol Biochem 43:10511058

Plaza C, Courtier-Murias D, Fernández JM, Polo A, Simpson AJ (2013) Physical, chemical, and biochemical mechanisms of soil organic matter stabilization under conservation tillage systems: A central role for microbes and microbial by-products in $\mathrm{C}$ sequestration. Soil Biol Biochem 57:124135

Post WM, Kwon KC (2000) Soil carbon sequestration and land-use change: Processes and potential. Glob Change Biol 6:317-327

Prahl FG, Ertel JR, Goñi MA, Eversmeyer B (1994) Terrestrial organic carbon contributions to sediments on the Washington margin. Geochim Cosmochim Acta 58:3035-3048

Quénéa K, Largeau C, Derenne S, Spaccini R, Bardoux G, Mariotti A (2006) Molecular and isotopic study of lipids in particle size fractions of a sandy cultivated soil (Cestas cultivation sequence, southwest France): Sources, degradation, and comparison with Cestas forest soil. Org Geochem 37:20-44

Riederer M, Matzke K, Ziegler F, Kögel-Knabner I (1993) Occurrence, distribution and fate of the lipid plant biopolymers cutin and suberin in temperate forest soils. Org Geochem 20:1063-1076

Rumpel C, Rabia N, Derenne S, Quenea K, Eusterhues K, Kögel-Knabner I, Mariotti A (2006) Alteration of soil organic matter following treatment with hydrofluoric acid (HF). Org Geochem 37:1437-1451

Rumpel C, Chabbi A (2010) Response of bulk chemical composition, lignin and carbohydrate signature to grassland conversion in a ley-arable cropping system. Nutr Cycl Agroecosyst 88:173-182

Ruzicka S, Edgerton D, Norman M, Hill T (2000) The utility of ergosterol as a bioindicator of fungi in temperate soils. Soil Biol Biochem 32:989-1005

Salloum MJ, Dudas MJ, McGill WB, Murphy SM (2000) Surfactant sorption to soil and geologic samples with varying mineralogical and chemical properties. Environ Toxicol Chem 19:2436-2442

Schmidt MWI, Knicker H, Hatcher PG, Kögel-Knabner I (1997) Improvement of 13C and 15N CPMAS NMR spectra of bulk soils, particle size fractions and organic material by treatment with $10 \%$ hydrofluoric acid. Eur J Soil Sci 48:319-328

Schulten HR, Monreal CM, Schnitzer M (1995) Effect of long-term cultivation on the chemical structure of soil organic matter. Naturwissenschaften 82:42-44

Shaver GR, Canadell J, Chapin FS, Gurevitch J, Harte J, Henry G, Ineson P, Jonasson S, Melillo J, Pitelka L, Rustad L (2000) Global warming and terrestrial ecosystems: A conceptual framework for analysis. Bio Sci 50:871-882 
Simoneit BRT (2005) A review of current applications of mass spectrometry for biomarker/molecular tracer elucidations. Mass Spectrom Rev 24:719-765

Simoneit BRT, Elias VO, Kobayashi M, Kawamura K, Rushdi AI, Medeiros PM, Rogge WF, Didyk BM (2004) Sugars - dominant water-soluble organic compounds in soils and characterization as tracers in atmospheric particulate matter. Environ Sci Technol 38:5939-5949

Simpson AJ, Simpson MJ, Soong R (2012) Nuclear magnetic resonance spectroscopy and its key role in environmental research. Environ Sci Technol 46:11488-11496

Simpson MJ, Hatcher PG (2004) Determination of black carbon in natural organic matter by chemical oxidation and solid-state 13C nuclear magnetic resonance spectroscopy. Org Geochem 35:923-935

Simpson MJ, Otto A, Feng X (2008) Comparison of solid-state carbon-13 nuclear magnetic resonance and organic matter biomarkers for assessing soil organic matter degradation. Soil Sci Am J 72:268276

Simpson MJ, Simpson AJ (2012) The chemical ecology of soil organic matter molecular constituents. J Chem Ecol 38:768-784

Six J, Elliott ET, Paustian K (2000) Soil macroaggregate turnover and microaggregate formation: A mechanism for $\mathrm{C}$ sequestration under no-tillage agriculture. Soil Biol Biochem 32:2099-2103

Six J, Frey SD, Thiet RK, Batten KM (2006) Bacterial and fungal contributions to carbon sequestration in agroecosystems. Soil Sci Soc Am J 70:555-569

Stevenson FJ (1982) Humus Chemistry: Genesis, Composition, Reactions. Wiley, New York.

Thenot JP, Horning EC, Stafford M, Horning MG (1972) Fatty acid esterification with N,Ndimethylformamide dialkyl acetals for GC analysis. Anal Lett 5:217-223

Thevenot M, Dignac M, Rumpel C (2010) Fate of lignins in soils: A review. Soil Biol Biochem 42:1200-1211

Trumbore SE, Czimczik CI (2008) An uncertain future for soil carbon. Science 321:1455-1456

Volkman JK (2003) Sterols in microorganisms. Appl Microbiol Biotechnol 60:495-506

Waksman SA (1929) Chemical and microbiological principles underlying the decomposition of green manures in the soil. J Am Soc Agron 21:1-18

Wingler A (2002) The function of trehalose biosynthesis in plants. Phytochemistry 60:437-440 
Table 1. Characteristics of the soil samples collected in native grassland (NG), cultivated (C), native forest (NF) and pasture (P) sites including soil type classification and texture (percent sand, silt and clay), mean annual temperature (MAT) and precipitation (MAP), dominant vegetation and type of cultivation, soil $\mathrm{pH}$, percent organic carbon $(\mathrm{C})$ and carbon to nitrogen ratio $(\mathrm{C}: \mathrm{N})$.

\begin{tabular}{|c|c|c|c|c|c|c|c|c|c|c|c|c|c|}
\hline $\begin{array}{l}\text { Sample } \\
\text { ID }\end{array}$ & Location & Latitude & Longitude & Soil Type & $\begin{array}{c}\text { Sand } \\
(\%)\end{array}$ & $\begin{array}{l}\text { Silt } \\
(\%)\end{array}$ & $\begin{array}{l}\text { Clay } \\
(\%)\end{array}$ & $\begin{array}{c}\text { MAT } \\
\left({ }^{\circ} \mathbf{C}\right)\end{array}$ & $\begin{array}{l}\text { MAP } \\
(\mathbf{m m})\end{array}$ & Vegetation/Cultivation & $\mathbf{p H}$ & $\begin{array}{l}\mathrm{C} \\
(\%)\end{array}$ & $\mathrm{C}: \mathbf{N}$ \\
\hline AL-NG & $\begin{array}{l}\text { Edmonton, } \\
\text { Alberta }\end{array}$ & $53^{\circ} 55^{\prime} \mathrm{N}$ & $113^{\circ} 50^{\prime} \mathrm{W}$ & Udic Borroll & 30 & 55 & 15 & 2 & 452 & $\begin{array}{l}\text { Grassland, } \mathrm{C}_{3} \text { fescue } \\
\text { grasses }\end{array}$ & 6.22 & 5.3 & 13.2 \\
\hline AL-C & $\begin{array}{l}\text { Melfort, } \\
\text { Saskatchewan }\end{array}$ & $52^{\circ} 52^{\prime} \mathrm{N}$ & $104^{\circ} 36^{\prime} \mathrm{W}$ & Udic Borroll & 9 & 50 & 40 & 1 & 411 & $\begin{array}{l}\text { Continuous corn } \\
\text { cultivation }\end{array}$ & 5.41 & 5.1 & 10.2 \\
\hline SK-NG & $\begin{array}{l}\text { Indian Head, } \\
\text { Saskatchewan }\end{array}$ & $50^{\circ} 53^{\prime} \mathrm{N}$ & $103^{\circ} 52^{\prime} \mathrm{W}$ & Udic Borroll & 29 & 21 & 50 & 2 & 427 & $\begin{array}{l}\text { Grassland, cool season } \\
\text { grasses }\end{array}$ & 7.40 & 3.7 & 10.4 \\
\hline SK-C & $\begin{array}{l}\text { Indian Head, } \\
\text { Saskatchewan }\end{array}$ & $50^{\circ} 53^{\prime} \mathrm{N}$ & $103^{\circ} 52^{\prime} \mathrm{W}$ & Udic Borroll & 28 & 11 & 61 & 2 & 427 & $\begin{array}{l}\text { Spring wheat crop } \\
\text { rotations }\end{array}$ & 8.05 & 2.3 & 11.2 \\
\hline ND-NG & $\begin{array}{l}\text { Mandan, North } \\
\text { Dakota }\end{array}$ & $46^{\circ} 77^{\prime} \mathrm{N}$ & $100^{\circ} 92^{\prime} \mathrm{W}$ & Typic Argiboroll & 25 & 46 & 28 & 5 & 402 & Warm mixed grass prairie & 6.58 & 3.2 & 11.0 \\
\hline ND-C & $\begin{array}{l}\text { Mandan, North } \\
\text { Dakota }\end{array}$ & $46^{\circ} 77^{\prime} \mathrm{N}$ & $100^{\circ} 92^{\prime} \mathrm{W}$ & Typic Argiboroll & 26 & 41 & 33 & 5 & 402 & $\begin{array}{l}\text { Continuous no-till spring } \\
\text { wheat }\end{array}$ & 5.89 & 2.8 & 11.7 \\
\hline $\mathrm{CO}-\mathrm{NG}$ & $\begin{array}{l}\text { Akron, } \\
\text { Colorado }\end{array}$ & $40^{\circ} 15^{\prime} \mathrm{N}$ & $103^{\circ} 15^{\prime} \mathrm{W}$ & Aridic Paleustoll & 36 & 41 & 23 & 9 & 420 & Grassland, $\mathrm{C}_{4}$ grasses & 7.00 & 1.2 & 8.6 \\
\hline $\mathrm{CO}-\mathrm{C}$ & $\begin{array}{l}\text { Akron, } \\
\text { Colorado }\end{array}$ & $40^{\circ} 15^{\prime} \mathrm{N}$ & $103^{\circ} 15^{\prime} \mathrm{W}$ & Aridic Paleustoll & 39 & 33 & 28 & 9 & 420 & $\begin{array}{l}\text { Continuous till wheat- } \\
\text { fallow treatments }\end{array}$ & 6.41 & 0.7 & 6.9 \\
\hline TX-NG & Vernon, Texas & $33^{\circ} 94^{\prime} \mathrm{N}$ & $99^{\circ} 40^{\prime} \mathrm{W}$ & Typic Paleustoll & 17 & 52 & 31 & 17 & 665 & $\begin{array}{l}\text { Grassland, mix of } \mathrm{C}_{3} \text { and } \\
\mathrm{C}_{4} \text { grasses }\end{array}$ & 7.47 & 1.1 & 8.9 \\
\hline TX-C & Vernon, Texas & $33^{\circ} 94^{\prime} \mathrm{N}$ & $99^{\circ} 40^{\prime} \mathrm{W}$ & Typic Paleustoll & 15 & 41 & 44 & 17 & 665 & $\begin{array}{l}\text { Continuous wheat with } \\
\text { conventional tillage }\end{array}$ & 7.95 & 1.0 & 8.1 \\
\hline CR-NF & $\begin{array}{l}\text { Alajuela, Costa } \\
\text { Rica }\end{array}$ & N/A & N/A & Hydric Melanudand & 68 & 23 & 9 & 20 & 2700 & $\begin{array}{l}\text { Tropical forest, mostly } \mathrm{C}_{3} \\
\text { species }\end{array}$ & 5.22 & 20.0 & 12.1 \\
\hline CR-P & $\begin{array}{l}\text { Alajuela, Costa } \\
\text { Rica }\end{array}$ & N/A & N/A & Hydric Melanudand & 61 & 27 & 12 & 20 & 2700 & Warm season grasses, $\mathrm{C}_{4}$ & 5.49 & 14.2 & 13.5 \\
\hline BR-NF & $\begin{array}{l}\text { Rondônia, } \\
\text { Brazil }\end{array}$ & $10^{\circ} 17^{\prime} \mathrm{N}$ & $62^{\circ} 82^{\prime} \mathrm{W}$ & Paleudult \& Kandiuldult & 60 & 10 & 30 & 26 & 2200 & $\begin{array}{l}\text { Tropical forest, mostly } \mathrm{C}_{3} \\
\text { species }\end{array}$ & 4.33 & 1.1 & 8.7 \\
\hline BR-P & $\begin{array}{l}\text { Rondônia, } \\
\text { Brazil }\end{array}$ & $10^{\circ} 17^{\prime} \mathrm{N}$ & $62^{\circ} 82^{\prime} \mathrm{W}$ & Paleudult \& Kandiuldult & 65 & 10 & 25 & 26 & 2200 & Warm season grasses, $\mathrm{C}_{4}$ & 5.59 & 1.4 & 10.6 \\
\hline
\end{tabular}

Land management at each site began in the following years: Alberta (AL; 1958), Saskatchewan (SK; 1907), North Dakota (ND; 1910), Colorado (CO; 1907), Texas (TX; 1980), Costa Rica (CR; 1979) and Brazil (BR; 1972).

Table information was taken from Haddix et al. (2011) and references therein.

AL-NG soil characteristics were taken from Janzen et al. (1998), soil texture from Salloum et al. (2000), soil pH from Mitchell and Simpson (2013), and elemental composition from Otto et al. (2005). 
Table 2. Percent soil organic carbon (SOC) respired, percent of the total ion intensity (\% TII) of the sum of carbohydrates, peptides and N-containing compounds detected with Pyrolysis-Molecular Beam Mass

Spectrometry (Py-MBMS), the relative contribution $(\%)$ of the four main carbon structures to the solid-state ${ }^{13} \mathrm{C}$ CP-MAS NMR spectra after integration and the resulting alkyl/O-alkyl ratios of the native and cultivated grassland and forest soils.

\begin{tabular}{|c|c|c|c|c|c|c|c|}
\hline & $\begin{array}{c}\text { SOC } \\
\text { Respired } \\
(\%)\end{array}$ & $\begin{array}{c}\text { Py-MBMS } \\
\text { Carb+Peptides } \\
+ \text { N Compounds } \\
(\% \text { TII })\end{array}$ & $\begin{array}{c}\text { Alkyl C } \\
\text { (0-50 ppm) }\end{array}$ & $\begin{array}{c}O \text {-Alkyl C } \\
\text { (50-110 ppm) }\end{array}$ & $\begin{array}{c}\text { Aromatic and } \\
\text { Phenolic C } \\
(\mathbf{1 1 0 - 1 6 5} \text { ppm) }\end{array}$ & $\begin{array}{c}\text { Carboxylic and } \\
\text { Carbonyl C } \\
(165-215 \text { ppm) }\end{array}$ & $\begin{array}{c}\text { Alkyl/ } O \\
\text { Alkyl }\end{array}$ \\
\hline \multicolumn{8}{|c|}{ Grassland soils } \\
\hline AL-NG & $n a$ & $n a$ & 27 & 33 & 33 & 7 & 0.82 \\
\hline AL-C & 6.1 & na & 25 & 38 & 27 & 10 & 0.67 \\
\hline SK-NG & 10.4 & 34 & 32 & 44 & 15 & 9 & 0.73 \\
\hline SK-C & 7.3 & 26 & 32 & 41 & 16 & 11 & 0.77 \\
\hline ND-NG & 8.9 & 33 & 29 & 37 & 24 & 10 & 0.78 \\
\hline ND-C & 9.2 & 33 & 29 & 40 & 21 & 10 & 0.72 \\
\hline $\mathrm{CO}-\mathrm{NG}$ & 17.9 & 30 & 31 & 42 & 16 & 12 & 0.74 \\
\hline $\mathrm{CO}-\mathrm{C}$ & 13.0 & 26 & 29 & 31 & 26 & 14 & 0.94 \\
\hline TX-NG & 15.0 & 29 & 31 & 36 & 20 & 13 & 0.88 \\
\hline TX-C & 15.4 & 25 & 32 & 31 & 24 & 13 & 1.04 \\
\hline \multicolumn{8}{|c|}{ Forest soils } \\
\hline CR-NF & 4.2 & 42 & 25 & 52 & 18 & 5 & 0.47 \\
\hline CR-P & 2.9 & 40 & 23 & 51 & 16 & 11 & 0.44 \\
\hline BR-NF & 11.1 & 32 & 41 & 37 & 15 & 7 & 1.10 \\
\hline BR-P & 10.6 & 35 & 31 & 46 & 17 & 6 & 0.68 \\
\hline
\end{tabular}

na $=$ not analyzed.

SOC respired and Py-MBMS data was taken from Haddix et al. (2011).

AL-NG ${ }^{13}$ C NMR data was taken from Mitchell and Simpson (2013). 


\section{Figure Captions}

Figure 1. The relative abundance (\%) of the total solvent-extractable lipids of microbial and plant origin in the native and cultivated soils collected along the mean annual temperature (MAT) gradient. The microbial components include: short-chain saturated and unsaturated alkyl compounds $\left(<\mathrm{C}_{20}\right)$ and the sterols cholesterol and ergosterol. Plant components include: long-chain alkyl compounds $\left(\geq C_{20}\right)$; the sterols campesterol, stigmasterol and $\beta$-sitosterol; the triterpenoids $\beta$ - and $\alpha$-amyrin, lupeol and ursolic acid; ferulic acid. Bars are averages of triplicate analyses and the error bars indicate standard error. Significant differences $(P \leq 0.05)$ in microbial or plant components between sites for the native and cultivated soils are indicated by different letters: Microbial components between the native soils (lowercase), microbial components between the cultivated soils (lowercase italics), plant components between the native soils (uppercase) and plant components between the cultivated soils (uppercase italics). Significant differences $(P \leq 0.05)$ in microbial or plant components between native and cultivated soils at each site are indicated by an asterisk.

Figure 2. Changes in the amount of molecular and bulk SOM components since the time of conversion from native grassland/forest to cultivated/pasture land-use calculated using Equation 1. Changes in: (a) free microbial- (short-chain saturated and unsaturated alkyl compounds $\left(<\mathrm{C}_{20}\right)$; the sterols cholesterol and ergosterol) and plant-derived compounds (long-chain alkyl compounds $\left(\geq \mathrm{C}_{20}\right)$; the sterols campesterol, stigmasterol and $\beta$-sitosterol; the triterpenoids $\beta$ - and $\alpha$-amyrin, lupeol, ursolic acid; ferulic acid), (b) bound suberin- $\left(\mathrm{C}_{20}-\mathrm{C}_{32} \omega\right.$-hydroxyalkanoic acids; $\mathrm{C}_{20}-\mathrm{C}_{32} \alpha, \omega$-dioic acids) and cutin-derived lipids $\left(\mathrm{C}_{16}\right.$ mono-, dihydroxy acids and diacids), (c) syringyl, vanillyl and cinnamyl lignin phenols and (d) bulk SOM components from ${ }^{13} \mathrm{C}$ CP-MAS NMR integration data. Bars are averages of triplicate analyses and the error bars indicate standard error.

Figure 3. Cutin and suberin inputs to the native and cultivated soils collected along the mean annual temperature (MAT) gradient: (a) The suberin to cutin ratio $(\mathrm{S} / \mathrm{C})$ and (b) the cutin source and degradation parameter $\omega-\mathrm{C}_{16} / \Sigma \mathrm{C}_{16}$. Both ratios were calculated according to Otto and Simpson (2006a). Data points are averages of triplicate analyses and the error bars indicate standard error. Significant differences $(P \leq 0.05)$ between sites for the native and cultivated soils are indicated by different lowercase letters. Significant differences $(P \leq 0.05)$ between native and cultivated soils are indicated by an asterisk.

Figure 4. Lignin source and degradation parameters for the native and cultivated soils collected along the mean annual temperature (MAT) gradient: (a) The cinnamyl/vanillyl (C/V) and syringyl/vanillyl $(\mathrm{S} / \mathrm{V})$ phenol ratios and (b) the lignin acid/aldehyde ratios for vanillyl $(\mathrm{Ad} / \mathrm{Al}) \mathrm{v}$ and syringyl $(\mathrm{Ad} / \mathrm{Al}) \mathrm{s}$ monomers. Grassland $(\circ)$ and forest $(\square)$ soil samples; black $=$ native soils, white $=$ cultivated and pasture soils. Data points are averages of triplicate analyses and the error bars indicate standard error. Statistics for these figures are included in the Supplementary Table S5.

Figure 5. Comparison of the solid-state ${ }^{13} \mathrm{C}$ cross polarization magic angle spinning (CP-MAS) nuclear magnetic resonance (NMR) spectra of a native grassland (North Dakota) and forest (Brazil) soil with the corresponding cultivated and pasture soils. 
Figure 1.

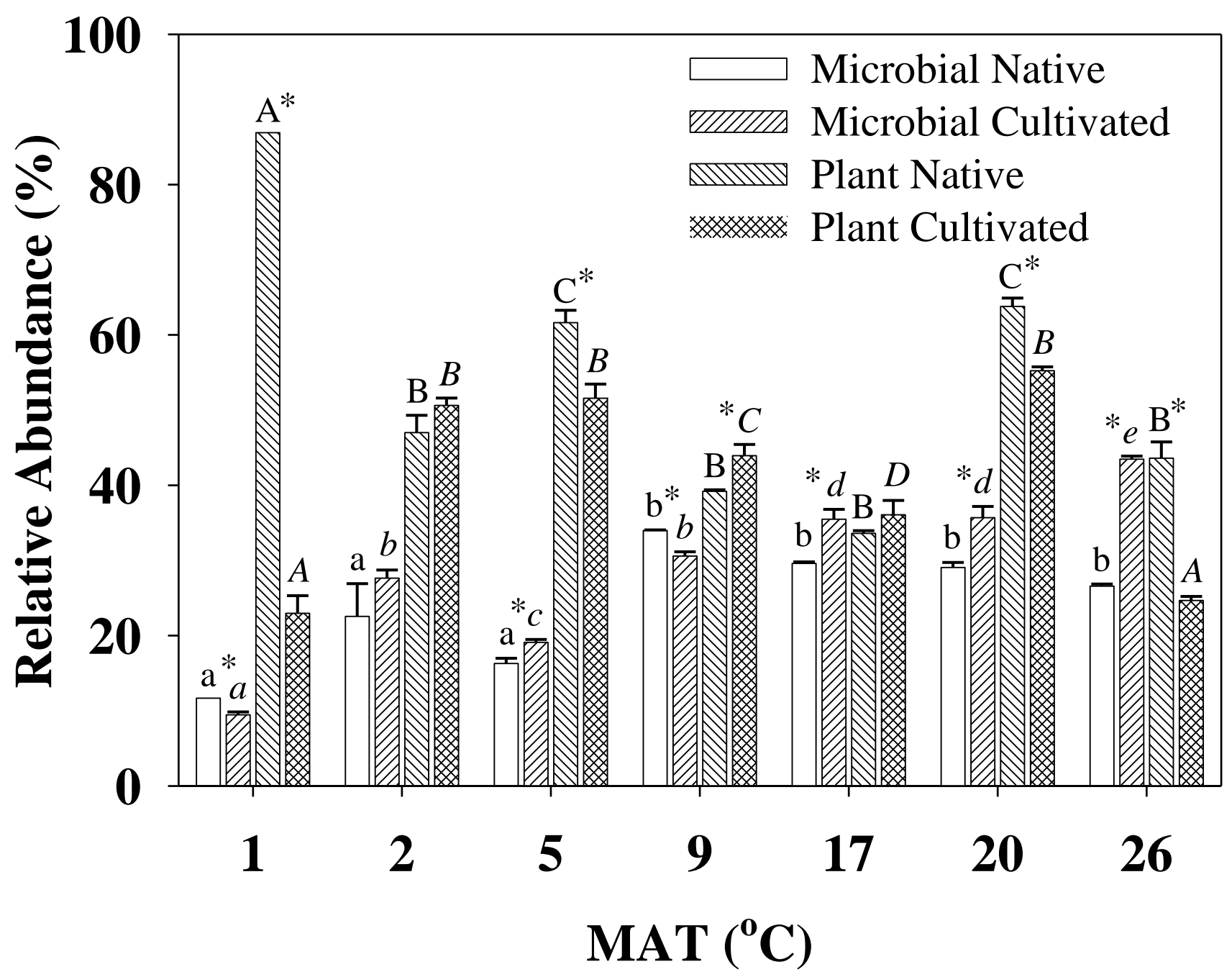


Figure 2.
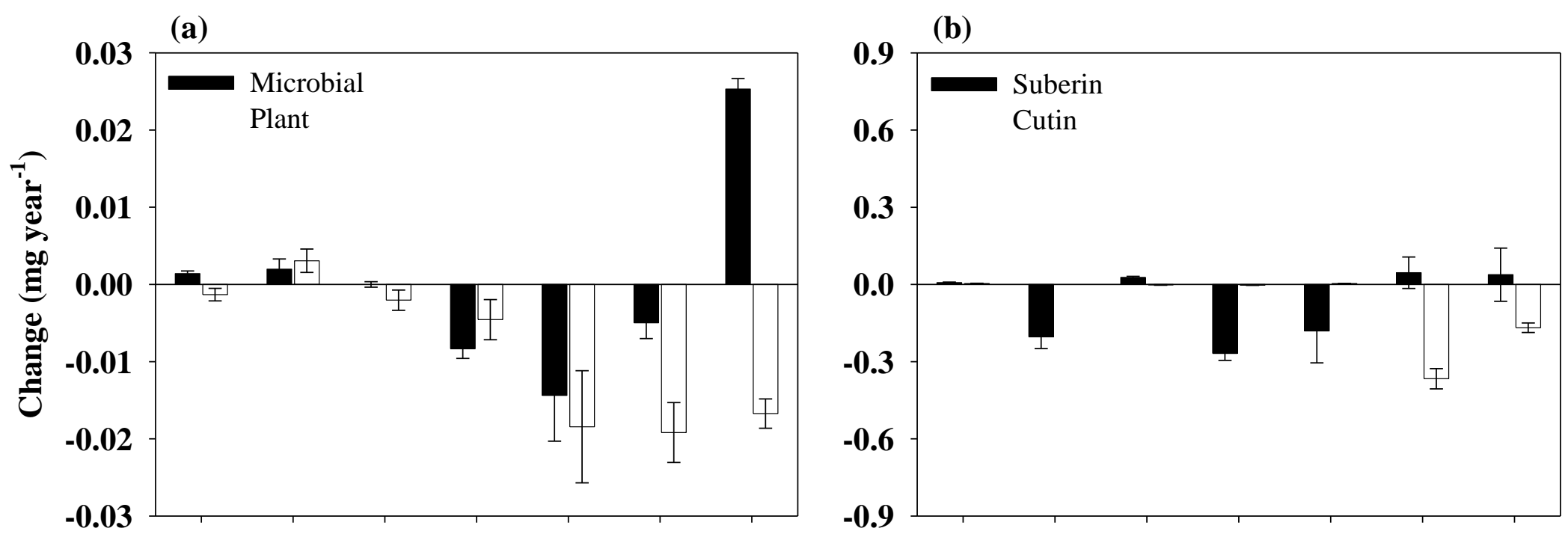

(c)
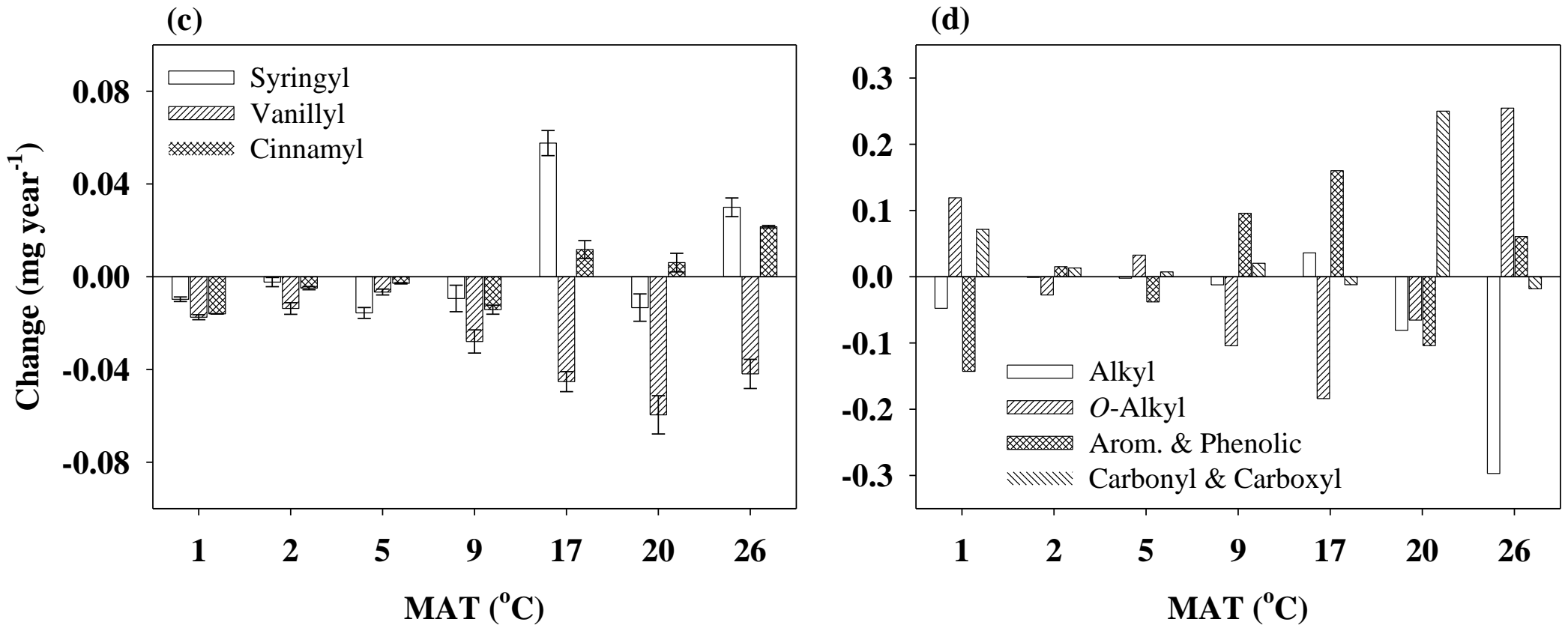
Figure 3.
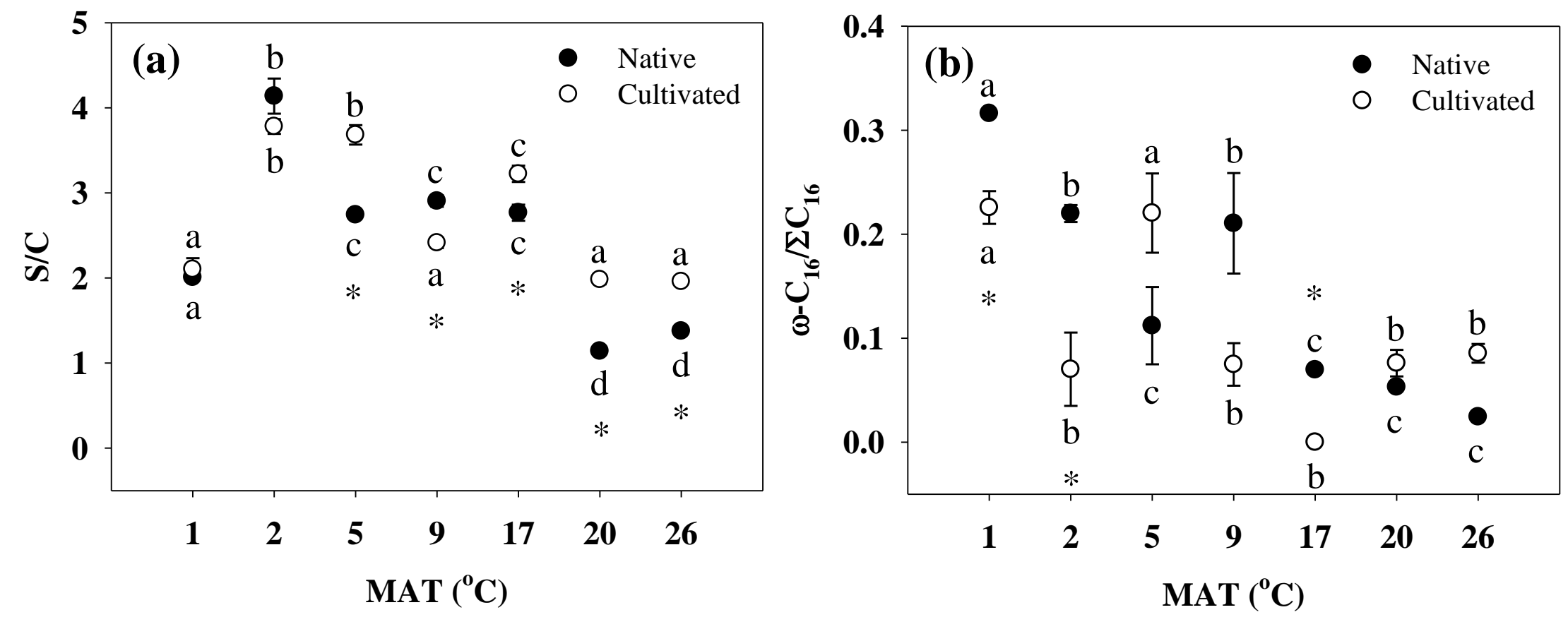
Figure 4.
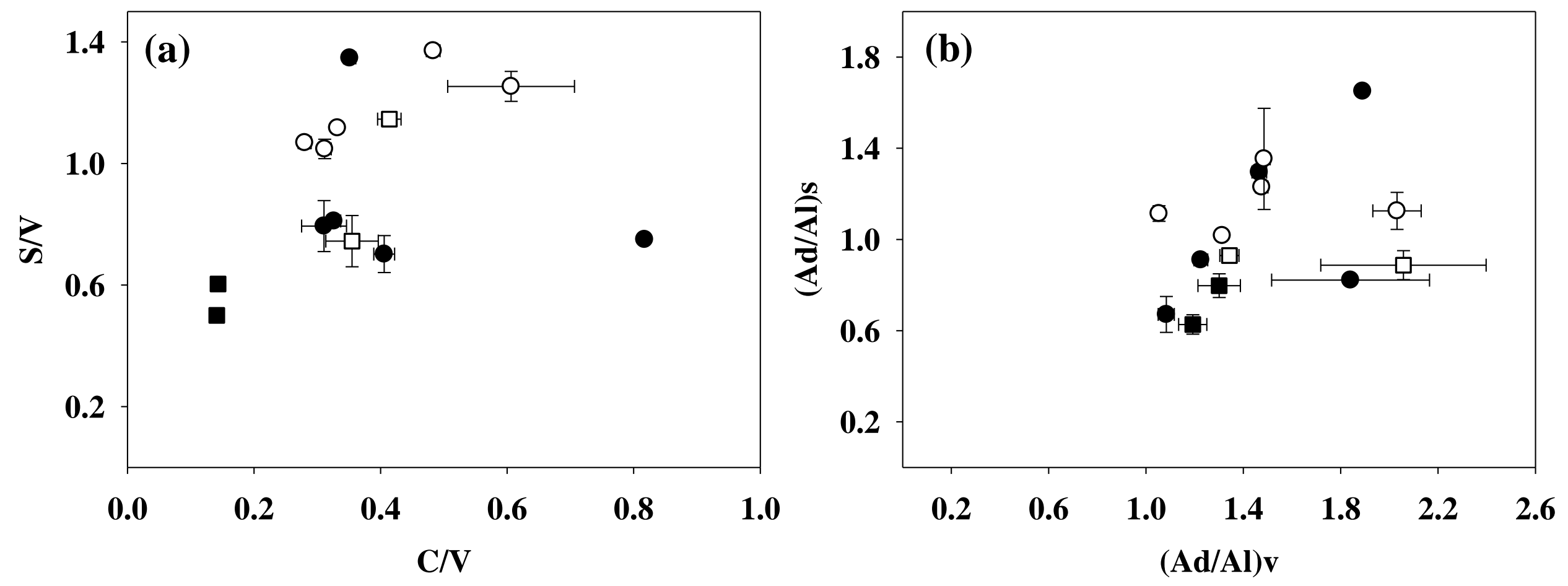
Figure 5.
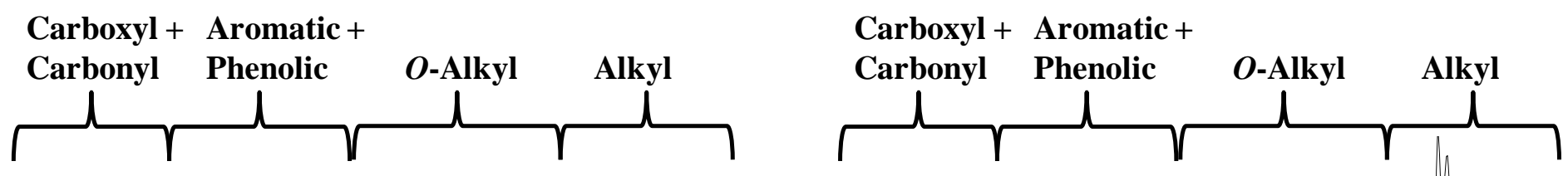

\section{North Dakota}

Native grassland

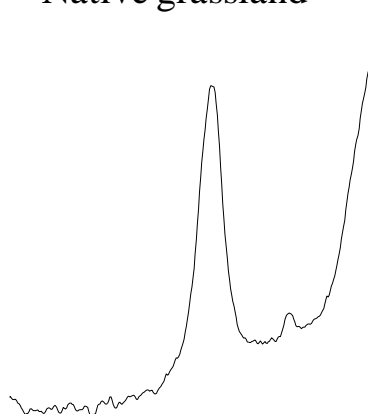

North Dakota

Cultivated
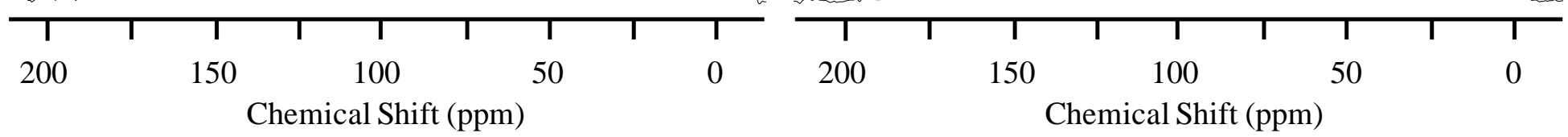


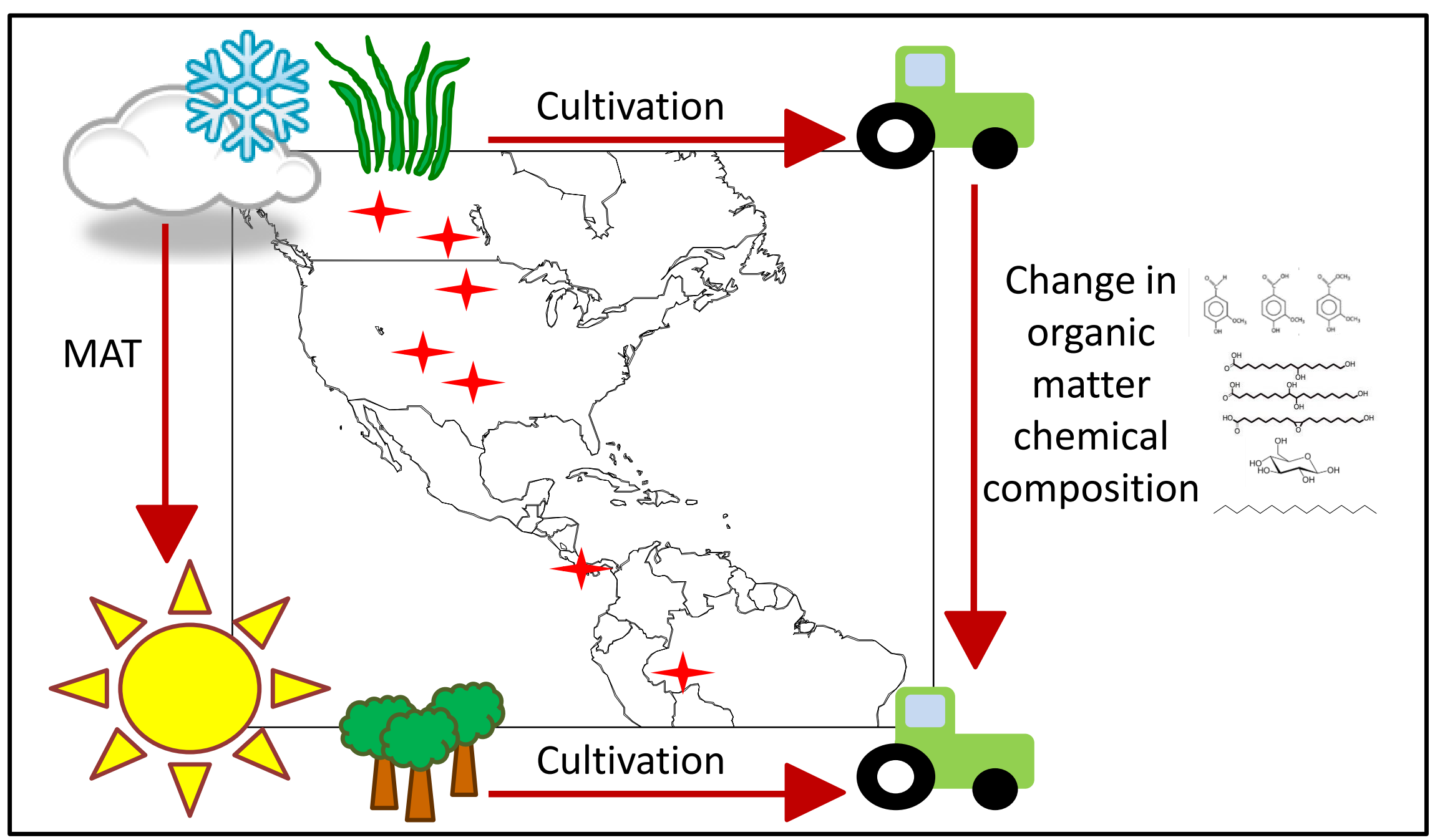

